\title{
Knowledge and Awareness of Sickle Cell Trait among NCAA Division I FBS, Division I FCS, Division II, and Division III Head Football Coaches and Strength and Conditioning Specialists
}

Timothy D. Yates

West Virginia University

Follow this and additional works at: https://researchrepository.wvu.edu/etd

\author{
Recommended Citation \\ Yates, Timothy D., "Knowledge and Awareness of Sickle Cell Trait among NCAA Division I FBS, Division I \\ FCS, Division II, and Division III Head Football Coaches and Strength and Conditioning Specialists" (2013). \\ Graduate Theses, Dissertations, and Problem Reports. 649. \\ https://researchrepository.wvu.edu/etd/649
}

This Thesis is protected by copyright and/or related rights. It has been brought to you by the The Research Repository @ WVU with permission from the rights-holder(s). You are free to use this Thesis in any way that is permitted by the copyright and related rights legislation that applies to your use. For other uses you must obtain permission from the rights-holder(s) directly, unless additional rights are indicated by a Creative Commons license in the record and/ or on the work itself. This Thesis has been accepted for inclusion in WVU Graduate Theses, Dissertations, and Problem Reports collection by an authorized administrator of The Research Repository @ WVU. For more information, please contact researchrepository@mail.wvu.edu. 
Knowledge and Awareness of Sickle Cell Trait among NCAA Division I FBS, Division I FCS, Division II, and Division III Head Football Coaches and Strength and Conditioning Specialists.

\author{
Timothy D. Yates, ATC
}

Thesis submitted to the College of Physical Activity and Sport Sciences at West Virginia University in partial fulfillment of the requirements for the degree of

\author{
Master of Science in Athletic Training \\ Michelle A. Sandrey, PhD, ATC, Chair \\ Benjamin Moorehead, MD \\ Vanessa Shannon, PhD, CC-AASP
}

Department of Athletic Training

Morgantown, WV

2013

Key words: sickle cell trait, sports, coach, strength and conditioning 
Knowledge and Awareness of Sickle Cell Trait among NCAA Division I FBS, Division I FCS, Division II, and Division III Head Football Coaches and Strength and Conditioning Specialists.

\section{Timothy D. Yates, ATC}

Context: Sickle Cell Trait (SCT) is becoming more prevalent among all levels of athletics, and is most commonly present among football players at the collegiate level. Sickle Cell Trait in association with exertional rhabdomyolysis is the leading killer among NCAA Division I football players, and has taken the lives of nine athletes ranging in age from 12-19 in the past 7 years. Nearly all of the deaths in collegiate athletics related to Sickle Cell Trait have occurred without a Certified Athletic Trainer present. Therefore, the knowledge and awareness of the condition among head football coaches and strength and conditioning specialists needs to be examined in an attempt to avoid this life threatening condition. Objective: The purpose of this study is to examine the knowledge of Sickle Cell Trait among head football coaches and strength and conditioning specialists within all three NCAA Divisions. Additionally, a second purpose is to identify whether or not head football coaches and strength and conditioning specialists present awareness and confidence to provide the proper treatment and/or referral for an athlete suffering from an exercise-related event due to Sickle Cell Trait. Design: This study is a descriptive prospective questionnaire analysis of the knowledge and awareness of Sickle Cell Trait among collegiate head football coaches and strength and conditioning specialists. Setting: Head football coaches and strength and conditioning specialists of NCAA Division I FBS, Division I FCS, Division II, and Division III institutions across the country. Patients and Other Participants: 71 head football coaches and strength and conditioning specialists from NCAA Division I FBS, Division I FCS, Division II, and Division III institutions completed the survey. This was a sample of convenience selected from all institutions in the United States. Criteria for inclusion were: 1) Being a head football coach at any NCAA Division; and 2) Being a head strength and conditioning specialist for an NCAA football team at any institution. Interventions: Participants were contacted via e-mail and provided a link to the initial cover letter and questionnaire. One online questionnaire was used for this study; the same questionnaire was used for both professionals. The knowledge and awareness survey was developed as there are none present in the literature. A follow-up e-mail was sent to participants within two weeks following initial contact to remind them to complete the questionnaire. Main Outcomes Measures: Knowledge, awareness, and confidence of Sickle Cell Trait via an on-line questionnaire. Results: Of the 959 total emails sent to NCAA head football coaches and strength and conditioning specialists, 71 began the survey and 59 completed the knowledge section for a return rate of $6.2 \%$, while only $49(5.1 \%)$ completed the demographic section. There were twenty (40.8\%) head football coaches and twenty-nine strength and conditioning specialists (59.2\%). The majority of participants $(40.8 \%, \mathrm{n}=21)$ were from NCAA Division III and the least $(14.3 \%, \mathrm{n}=7)$ were from NCAA Division I FBS. Sixty-eight of the 71 participants who began the survey reported they had heard of SCT previously. The top three sources selected for where participants obtained knowledge of SCT were 1) certified athletic trainer $(67.8 \%, \mathrm{n}=40) ; 2)$ experience with an athlete $(47.5 \%$, $\mathrm{n}=28)$; and 3) college course (39.0\%, $\mathrm{n}=23)$. The top three signs and symptoms selected that may be associated with SCT were 1) muscle weakness $(72.9 \%, \mathrm{n}=43)$; 2 ) sensation of cramping muscles $(64.4 \%, \mathrm{n}=38)$; and 3$)$ sudden collapse $(50.8 \%, \mathrm{n}=30)$, which were all correct responses. 
Participants ranked confidence in recognizing signs and symptoms of and SCT event on a scale of 1-10 (1=not at all confident, 10=very confident), reporting a mean rank of $5.37 \pm 3.13$.

Participants also ranked confidence in making appropriate referral decisions in the event of a SCT event, reporting a mean rank of $6.12 \pm 3.19$. Strength and conditioning specialists ranked confidence in recognizing signs and symptoms and making appropriate referral decisions significantly higher than head football coaches $(\mathrm{P}=.002$ and $\mathrm{P}=.005$, respectively). Significant results were seen between divisions for ranking confidence in recognizing signs and symptoms. Individuals in Division I FBS ranked confidence significantly higher than individuals in Division II ( $\mathrm{P}=.048)$ and Division III ( $\mathrm{P}=.02)$. Subjects from Division I FCS ranked confidence significantly higher than individuals in Division III $(\mathrm{P}=.02)$. No significant results were found in ranking between Division I FBS and Division I FCS. Three scenarios, two of which resembled a SCT event were scored and combined to create a total scenario score ( 9 correct responses). No significant results were found between groups or divisions regarding scenario scores. Collectively, individuals in Division I and strength and conditioning specialists, overall, scored higher on the scenarios. A significant correlation $(\mathrm{P}=.05)$ suggested that the higher the participants ranked confidence in signs and symptoms, the higher they scored on the scenarios. Conclusion: Based on the results of the study, although overall knowledge levels of SCT were low to moderate, strength and conditioning specialists reported more knowledgeable of SCT than head football coaches. A more confident than not confident ranking in signs and symptoms and referral decisions did not reflect high overall scores on scenarios, nor selecting all of the proper signs and symptoms of SCT. Knowledge levels of SCT among head football coaches and strength and conditioning specialists are what was expected, but are not as high as they should be. Proper education should be sought by these individuals and possibly provided by certified athletic trainers to raise knowledge and awareness levels in order to provide optimal safety for NCAA football athletes. 


\section{ACKNOWLEGEMENTS}

First, I'd like to thank my amazing parents who have supported me throughout my entire life no matter what roads I have traveled. Without your continuing support and encouragement, I would not have the possibilities available to me that I have today. Thank you for always believing in me, and raising me to be the man I am today. I hope I have made you as proud as you make me.

Thank you to my awesome fiancé. You have been the one constant in my ever-changing life over the past three years. Without you, I would not have the motivation to strive for excellence in everything I do. You are the rock that is the foundation on which the rest of my life will be built, and for that I thank you. I look forward to our future together in more ways than you will ever

know.

Thank you to my sweet grandparents, and my wonderful late great-grandmother. Without your love and support throughout my life, many of my accomplishments would not have been possible. It is so great to know I have such wonderful grandparents, which is a lost value to so many in today's age; thank you.

To my friends and classmates, thank you. We have been able to complain to one another and understand each other's struggles over the past few years; and without that sanity would have been lost long ago.

Thank you to Katie Eberst, Kyle Southall, and Zach Mohondro. Your help and support over the past two years at Waynesburg has no doubt helped me make it through alive. Thank you for all your help and understanding, as we all have so much more to learn and grow upon. I hope I have been able to be a help to you as well, and I will never forget any of you.

An immense thank you to the faculty and staff of the Waynesburg University Athletic Training Education Program. Without your support and encouragement over the past two years, I would not be the young professional I am today. Thank you so much for the values and character you have instilled in me during my time here, and I hope that one day I can repay you somehow. I will never forget you, and you will be missed.

To the students of Waynesburg University Athletic Training Education Program, thank you. Thank you for listening and putting up with me on a daily basis. Thank you for helping me grow as a mentor and an educator. I hope that I've taught you something along the way, as you have taught me more than you know.

Thank you to Dr. Michelle Sandrey and West Virginia University for the great opportunity to be a graduate assistant in the Athletic Training Program. Thank you, Dr. Sandrey, for believing in me and challenging me to always put forth my best, no matter what may stand in my way.

Thank you to Dr. Vanessa Shannon and Dr. Ben Moorehead for agreeing to give up your valuable time in order to be on the committee for this thesis. Without your expertise, most of what has come of this project would not have been possible, and for that I thank you. 


\section{TABLE OF CONTENTS}

ACKNOWLEDGEMENTS .........................................................

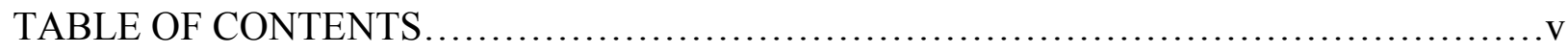

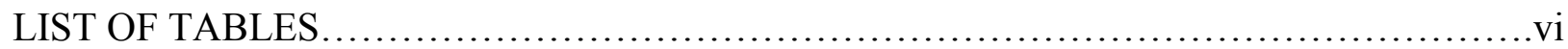

LIST OF FIGURES ........................................................

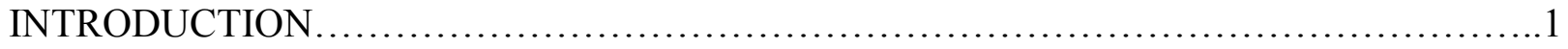

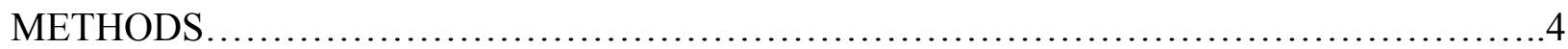

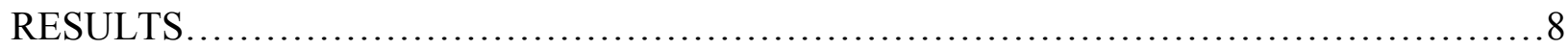

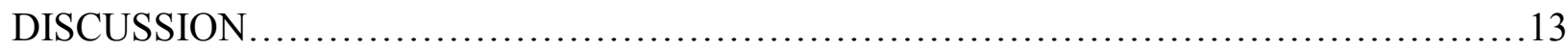

CONCLUSIONS............................................................... 19

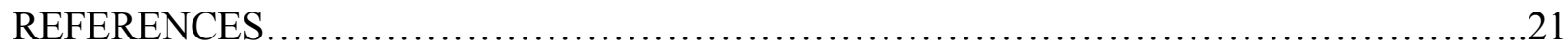

APPENDICES

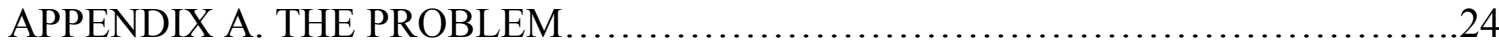

APPENDIX B. LITERATURE REVIEW ........................................ 31

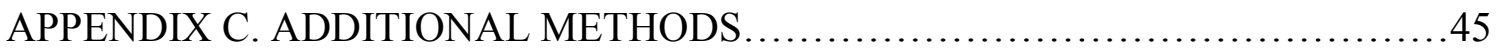

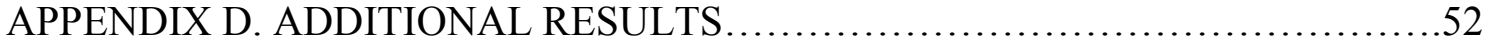

APPENDIX E. RECOMMENDATIONS FOR FUTURE RESEARCH..............56

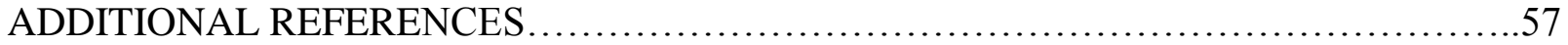




\section{LIST OF TABLES}

TABLE PAGE

Table B1. Common Differential Diagnoses of a Sickling Attack...........................36

Table B2. Recommendations for Prevention of Adverse Events Related to Sickle Cell Trait.....39

Table C1. Initial Cover Letter to Football Coaches and Strength and Conditioning Specialists...45

Table C2. Knowledge and Awareness of Sickle Cell Trait Questionnaire.....................46

Table C3. F/U Cover Letter to Football Coaches and Strength and Conditioning Specialists.....51

Table D1. NCAA Division of Employment and Position Title.............................52

Table D2. Where Knowledge of Sickle Cell Trait was Obtained...........................52

Table D3. Signs and Symptoms That May Associate with Sickle Cell Trait...................52

Table D4. Environmental Conditions that May Predispose Sickle Cell Trait Attack............53

Table D5. Comparison of Confidence with Signs and Symptoms and Referral and t Value.....53

Table D6. Tukey HSD Comparison in Signs and Symptoms Between NCAA Divisions.......53

Table D7. Total Scenario Scores..................................................... 54

Table D8. Comparison of Scenario Scores Between Professionals, t Values....................54

Table D9. ANOVA Comparison of Scenario Scores Between Divisions......................54

Table D10. Pearson Correlation between Confidence of Signs and Symptoms and Scenarios..55 


\section{LIST OF FIGURES}

FIGURE $\quad$ PAGE

Figure B1. Rhabdomyolysis Evaluation Algorithm.................................... 37 


\section{INTRODUCTION}

Sickle Cell Trait (SCT) is gaining more recognition within the sporting arena. SCT can be fatal to athletes in a variety of sports including football, basketball, and distance running. ${ }^{1,2,3,4,5,6,7}$ In the last twelve years, there have been sixteen deaths related to SCT in sports, ${ }^{2,7}$ among these are nine in the past seven years alone. ${ }^{7}$ Sickle Cell Trait ranks high among threats to life among high school and collegiate athletes, and first for National Collegiate Athletics Association (NCAA) Divison I football players in related deaths. ${ }^{2}$ Two million Americans from an estimated 100 million individuals worldwide are believed to carry SCT. Of these two million Americans, $8 \%$ of all African-Americans, $0.5 \%$ of Hispanic-Americans, and $0.2 \%$ Caucasian-Americans are estimated to be carriers of SCT. ${ }^{2,3}$

Sickle Cell Trait can be defined as a genetic condition that is characterized by one normal hemoglobin gene and one sickling (S) hemoglobin gene. ${ }^{1,7,8,9}$ This abnormality becomes dangerous with exertional sickling of red blood cells, which can occur with no warning. Red blood cells alter the shape due to lack of oxygen and collect within blood vessels. ${ }^{2,7}$ A potential complication of SCT is exertional rhabdomyolysis.

Exertional Rhabdomyolysis is a condition in which muscle tissue is subject to rapid breakdown due to lack of oxygen, which causes the contents of the muscle cell to spill out into the plasma. ${ }^{2,10}$ Rhabdomyolysis can lead to an acute attack, or can be an ongoing, chronic issue. Both are very dangerous; however, an acute attack becomes an immediate medical emergency. Individuals subject to exertional rhabdomyolysis are at risk of acute renal failure and splenic infarction, which can ultimately lead to death. ${ }^{2,10,11}$ 
Although SCT poses grave risks for athletes, it is commonly misdiagnosed among health care professionals and/or qualified individuals (i.e. Certified Athletic Trainers, head coaches, strength and conditioning specialists). ${ }^{12}$ Signs and symptoms of an event related to SCT can mimic those of a heat illness condition, a cardiac condition, or even asthma., ${ }^{2,712}$ These signs and symptoms may include muscle cramps, muscle weakness, full body pain, upper left quadrant abdominal pain, and/or shortness of breath. All these symptoms may be present with the aforementioned conditions as well; however, there are ways to differentiate between them. Thus Certified Atheltic Trainers (ATCs), head football coaches, and strength and conditioning specialists should possess proper and adequate education of the condition and be aware of how to manage a potentially dangerous situation.

All fifty states in the United States screen infants for SCT at birth, ${ }^{7,11}$ however, most are unaware if they carry the trait. Upon the condition gaining recognition among athletics, the National Athletic Trainers' Association (NATA) and the college of American Pathologists recommended in 2007 that all collegiate institutions begin requiring screenings for SCT during pre-participation physicals. In 2010, The NCAA implemented screening for all NCAA Division I institutions, and as of 2012, Division II institutions. The Division III level will join Division I and II by begin to implement screening as part of their pre-participation examinations in the fall of 2013. The athletes, at all Division levels, have the right to sign a waiver if they are unaware of or refuse to report their SCT carrying status. ${ }^{7,13,14}$ The NCAA was reluctant to begin screening for athletes, due to the ethical debate relating to prevalence of SCT among certain races. It was discussed to only screen targeted ethnicities.

The NATA and NCAA have recommended all individuals that may be involved with SCT (athlete, family, coaches, health care professional) be actively educated in the condition and 
associated complications. ${ }^{7,15}$ The NATA has taken this a step further by providing recommendations for prevention of sickling attacks. ${ }^{7,15,16}$ Among their recommendations are screening, education, alteration of exercise bouts for carriers, and a focus on hydration and other underlying risk factors. ${ }^{2,7,12,15,17,18,19}$ There are occasions in which a Certified Athletic Trainer is not present at practices or training sessions. Thus, it is important for coaches and strength and conditioning specialists to be knowledgeable and aware of SCT and its complications, especially what to do in the event of a sickling attack.

Despite the possible contact of a football coach and a strength and conditioning specialist with an athlete with SCT, there are no known studies examining the knowledge and awareness of those two groups of professionals. Therefore, this subject population should be evaluated. Head football coaches and strength and conditioning specialists in all NCAA Divisions should be knowledgeable and be held accountable for awareness of the seriousness of SCT, as well as to know how to react in the event of an attack during exertion if an ATC is not present. Thus, knowledge and awareness of head football coaches and strength and conditioning specialists are very important to prevent deaths. Hence, the purpose of this study will be to examine the knowledge of Sickle Cell Trait among head football coaches and strength and conditioning specialists within all three NCAA Divisions. Additionally, a second purpose is to identify whether or not head football coaches and strength and conditioning specialists present the awareness and confidence to provide the proper treatment and/or referral for an athlete suffering from an exercise-related event due to Sickle Cell Trait. There were three hypotheses used in this study based on the responses of the survey: 1) the majority of coaches and strength and conditioning specialists will not be educated overall of SCT; 2) strength and conditioning specialists will be more knowledgeable of SCT; and 3) Division I FBS and I FCS head football 
coaches and strength and conditioning specialists will be more knowledgeable of SCT than those individuals in Division II and III.

\section{METHODS}

Design

This is a prospective exploratory study that includes data from a 33 item online questionnaire. Knowledge of SCT among NCAA Divison I FBS, Division I FCS, Division II, and Division III head football coaches and head strength and conditioning specialists was studied. The research also explored whether head football coaches and strength and conditioning specialists present awareness and confidence to provide the proper treatment and/or referral during an exercise-related event due to SCT.

\section{Participants}

The participants were selected from a population 124 NCAA Division I (FBS), 122 Division I (FCS), 169 Division II, and 241 Division III head football coaches and head strength and conditioning specialists. Sampling the total number of football programs in each NCAA division eliminated sampling bias and assured geographical equality. Selection of the participants began from the NCAA website, where researchers were directed to the Athletics website that represents each institution. From the athletic website, contact information, including names and email addresses, of each head football coach and strength and conditioning specialist were obtained. Participants excluded from the study were head football coaches and strength and conditioning specialists who are not employed by NCAA Division I, II or III institution, as well as coaches whose contact email was not made available. Following exclusion criteria, 959 individuals were left to contact for this study. The study was approved by the Office of Research Compliance at West Virginia University. 
Instrumentation

The SCT knowledge and awareness questionnaire consisted of 33 questions including demographics, knowledge and awareness examination relating to epidemiology, presentation, complications, scenario awareness, and confidence levels relating to the participants' knowledge of SCT. There was also a scenario section in which the participant was required to answer questions related to a scenario that may or may not relate to SCT. The questionnaire was developed through objective review of literature, input from a physician familiar with SCT, and by examining questions and wordings from previous studies that examined the knowledge or perception of knowledge of various medical conditions related to sports. ${ }^{2,7,12,15-19}$ The demographic section of the questionnaire surveyed NCAA Division, position title, years spent at current position, degrees held, certifications held, total years employed as a head coach or strength and conditioning specialist, approximate number of athletes on their respective football teams, if they are a carrier of SCT, and if they have ever been in contact with an athlete who was a carrier of SCT. Included in this section were eight "forced-choice" questions and two "select all that apply" questions. The knowledge and awareness questions examined whether the participants had ever heard of SCT, where information was obtained about SCT, signs and symptoms associated with SCT, and confidence in recognizing signs and symptoms and making the appropriate referral decisions. Included in this section were one "forced-choice" question, three "select all that apply" questions, and four "rank scale" questions on a scale of 1-10 or 1-4 ( 1 being lowest rank, 10 or 4 being highest rank). Finally, the scenario awareness section of the questionnaire provided participants with three scenarios involving an athlete who may need care for an event resulting from SCT. Following each written scenario, there were five questions relating to that scenario. The same five questions were asked following all three scenarios. For 
each scenario there were two "forced-choice" questions, one "select all that apply" question, and two "rank scale" questions of 1-10 (1 being lowest rank, 10 being highest rank).

The questionnaire was reviewed by a head football coach, an assistant football coach, a head strength and conditioning specialist, and two certified athletic trainers at a Division III institution for reading and clarity. A psychometric expert experienced in research, questionnaires, and survey assisted in the creation and viewed the questionnaire for content and face validity.

Procedures

The head football coaches and strength and conditioning specialists from NCAA Division I FBS, Division I FCS, Division II, and Division III institutions were selected from each institution's athletic website, which was found via the NCAA website. To prevent sampling bias, all football programs (124 Division I FBS, 122 Division I FCS, 169 Division II, and 241 Division III) were chosen, and contact information was sought after for this study.

The link to the questionnaire was sent via e-mail to the head football coach and strength and conditioning specialist. The e-mail consisted of a short explanation of background information, and a link that directed them to Survey Monkey. Once clicking on the link, the participants were directed to the survey on Survey Monkey, which began with the cover letter explaining the procedures of the questionnaire, what the participant should do if they are willing to participate, and the rights of the participant (Table C1). Following the cover letter, the participants could select whether or not to continue with the survey (Table C2). A follow-up email (Table C3) was sent two weeks following the initial e-mail to the head football coaches and 
strength and conditioning specialists in attempt to further encourage participation. The participants were contacted during March prior to the beginning of spring football season.

The online questionnaire was contained on Survey Monkey's firewall protected server that restricts access to the database by any unapproved individuals. Data encryption and server authentication allows the researcher and Survey Monkey Web masters to be the only individuals with the ability to access the database. The responses to the questionnaire were automatically processed by a Common Gateway Interface (CGI) that was also protected by the university's firewall and had limited access for university employed web masters only. All data collected by the CGI was automatically inputted directly into Microsoft Excel and saved in a locked file.

\section{Data Analysis}

For data analysis the SCT questionnaire was divided into three sections (knowledge, scenario, and demographics). The survey responses of head football coaches and strength and conditioning specialists were compared on knowledge and performance on scenarios. Also compared were responses between NCAA Divisions.

The three scenarios were scored based on responses to the first three questions directly following each scenario (whether the scenario resembled SCT, which signs and symptoms helped the participant decide, and what would the participant do next). The remaining two questions following each scenario were not scored. One point was given if each question was answered in a fully correct fashion (i.e. selecting each correct answer choice on a "select all that apply," and selecting no wrong answer choices), for a total of three correct responses for each scenario. The three scenario scores were combined to create a total scenario score, with nine possible correct responses, which was used in statistical testing. 
Statistical Analysis

Descriptive statistics included means and standard deviations, as well as frequencies of responses. Independent Samples t-Tests were ran to compare scenario scores, confidence in recognizing signs and symptoms, and confidence in making appropriate referral decisions between head football coaches and strength and conditioning specialists. Additionally, one-way ANOVAs were completed to compare confidence in recognizing signs and symptoms as well as the total scenario scores between participants from each NCAA Division. Finally, a Pearson Correlation test was completed to explore any correlation between total scenario scores and how the participants answered the questions regarding confidence and familiarity with signs and symptoms of SCT. The P value for each analysis was set at $\mathrm{p}<0.05$. All data was analyzed using SPSS Version 21.0 for Windows.

\section{RESULTS}

Demographic Information

A total of 71 head football coaches and strength and conditioning specialists responded to the SCT knowledge and awareness survey. Twelve surveys were not completed in full; thus leaving a final response rate of 59, or 6.2 percent. Of those 59 responses, only 49 demographic surveys were useable. The majority of participants were from NCAA Division III institutions $(42.9 \%, \mathrm{n}=21)$ with the fewest participants from NCAA Division I FBS $(14.3 \%, \mathrm{n}=7)$. More strength and conditioning specialists $(59.2 \%, \mathrm{n}=29)$ than head football coaches $(40.8 \%, \mathrm{n}=20)$ participated in the study. See Table D1 for additional results on Division of employment and position title. Of the 29 strength and conditioning specialists who participated in the study, the majority $(93.1 \%, \mathrm{n}=27)$ had the Certified Strength and Conditioning Specialist (CSCS) certification, while much fewer $(10.3 \%, \mathrm{n}=3)$ had the National Academy of Sports Medicine 
Performance Enhancement Specialist (NASMPES) certification. Of the participants, the overwhelming majority $(93.9 \%, \mathrm{n}=46)$ were male, while one individual $(2.0 \%)$ was female and two $(4.1 \%)$ did not answer the question.

Knowledge of Sickle Cell Trait

Of the head football coaches and strength and conditioning specialists who participated, $68(95.8 \%)$ answered "Yes" to whether they had ever heard of Sickle Cell Trait (SCT), two (2.8\%) answered "No" and one (1.4\%) answered "I'm not sure". There were no missing data from this question, as everyone who opened the survey answered it. However, after this question there was a decline in participation with 12 individuals withdrawing, leaving 59 participants. When asked where the individuals obtained their knowledge of the condition, the participants selected all that applied from a list that included college courses, educational presentations, their certified athletic trainer, a professional conference, the NCAA Sports Medicine Handbook, journal articles, and/or experience with an athlete. The top three responses included certified athletic trainer $(67.8 \%, \mathrm{n}=40)$, experience with an athlete $(47.5 \%, \mathrm{n}=28)$, and a college course (39.0\%, $\mathrm{n}=23)$. See Table D2 for additional results. Participants were asked to select from a list of signs and symptoms the ones most commonly associated with SCT. There were four correct responses from the list of fifteen signs and symptoms. The four correct responses were muscle weakness, sudden collapse, abdominal pain, and sensation of cramping muscles. The top three responses for this question were muscle weakness $(72.9 \%, n=43)$, sensation of cramping muscles $(64.4 \%, \mathrm{n}=38)$, and sudden collapse $(50.8 \%, \mathrm{n}=30)$. Abdominal pain was the eighth most frequent response $(22.0 \%, \mathrm{n}=13)$. No participants selected only all four correct responses See Table D3 for additional results. Participants were asked to select all that apply from a list of environmental or physical conditions, which ones may predispose a carrier of SCT to an adverse 
attack. There were three correct responses including exercising in the heat, exercising at high altitude, and exercising while not properly hydrated. These three responses were the top three chosen; with exercising in the heat representing the most responses $(80.0 \%, \mathrm{n}=48)$, followed by exercising while not properly hydrated $(75.0 \%, \mathrm{n}=45)$, and then exercising at high altitude $(63.3 \%, \mathrm{n}=38)$. Nearly half $(46.7 \%, \mathrm{n}=28)$ of participants chose all three correct responses for this question. See Table D4 for additional results.

Participants were asked to rank their confidence level (1-10, 1 being "Not at all confident", 10 being "Very confident") with recognizing the signs and symptoms of a SCT attack. The mean response was $5.37 \pm 3.13$, which suggested that the participants are at best moderately confident in recognizing signs and symptoms of SCT. In the same fashion, participants were asked to rank their confidence in making the proper decisions and referrals during an attack caused by SCT. The response yielded a mean of $6.12 \pm 3.19$, which again suggested participants are moderately confident in making decisions based on referral and playing status when an individual suffers an attack from SCT. These two questions were also grouped into categories of "Confident" and "Not confident" based on responses to how many individuals reported being more confident than not on these questions. Reported responses of a 6 or higher on the scale of 1-10 were grouped into the "Confident" category, and responses of 5 and lower were grouped into the "Not confident" category. Frequencies showed that for confidence of recognizing signs and symptoms, although participants reported a moderate confidence ranking, more participants were confident $(55.9 \%, \mathrm{n}=33)$ than not confident $(44.1 \%$, $\mathrm{n}=26$ ). The same can be said for confidence of referral decisions, as there were more participants confident $(49.3 \%, \mathrm{n}=35)$ than not confident $(33.8 \%, \mathrm{n}=24)$. 
Independent Samples t-Tests were completed to compare how head football coaches and strength and conditioning specialists ranked confidence in signs and symptoms and referral decisions. Strength and conditioning specialists seem to be significantly more confident in recognizing signs and symptoms $(\mathrm{t}=-3.37, \mathrm{P}=.002)$. For confidence in recognizing signs and symptoms (rank scale from 1-10) the mean for strength and conditioning specialists was $6.50 \pm$ 2.58 , and for head football coaches $3.85 \pm 2.81$. Strength and conditioning specialists were more confident in making appropriate referral decisions as well $(\mathrm{t}=-2.94, \mathrm{P}=.005)$. The means for making the appropriate referral decisions during a SCT episode was $6.93 \pm 2.87$ for strength and conditioning specialists and $4.40 \pm 2.99$ for head football coaches. See Table D5 for additional results.

One-way ANOVAs were completed in order to compare confidence in recognizing signs and symptoms between NCAA Divisions. Individuals within NCAA Division I FBS reported the highest mean ranking of confidence $(8.00 \pm 1.673)$ and NCAA Division II individuals reported the lowest mean ranking $(4.54 \pm 2.537)$. Significant differences were noted between groups $\left(\mathrm{F}_{3,44}=5.563, \mathrm{P}=.003\right)$ which suggested that rankings differed across the groups of Divisions. Tukey's Post-Hoc examination revealed significant differences in confidence in recognizing signs and symptoms between Division I FCS and Division III (3.292, P=.02), Division I FBS and Division II (3.462, P=.048), Division I FBS and Division III (3.667, P=.02). This suggested that NCAA Division I, both FBS and FCS, ranked confidence higher in recognizing signs and symptoms of SCT. See Table D6 for additional results.

Scenarios

Participants were provided three scenarios immediately following the knowledge section of the survey. Each scenario was provided for the participant to read and a series of the same five 
questions followed all three scenarios. Participants were asked first if the scenario resembled SCT. Two scenarios resembled SCT (the first two), and one (the last one) did not. When participants answered "Yes" to the first question that resembled SCT, the next question on signs and symptoms was answered. If the participants answered "No" or "I'm not sure" on the scenarios that did resemble SCT, the next question was automatically skipped. The same question logic was added to the scenario that did not resemble SCT. If the participant answered "Yes", the signs and symptoms question was answered next. This was to see why the scenario resembled SCT when in fact it did not. The first three questions "did the above scenario resemble SCT?", "which signs and symptoms helped conclude this?", and "what would you do next?" were scored to create a total score for each scenario. Of these three questions, the second and third were "select all that apply" questions. If the participants did not select all possible answer choices for each question, no point was received for that question. There were three possible points for each scenario. The scenario scores were combined to create a total scenario score, with nine possible points.

When evaluating the total scenario score, descriptive statistics show that the majority of participants $(19.7 \%, \mathrm{n}=14)$ received 5 out of 9 points in the scenario section, suggesting consistency with the moderate confidence ranking in recognizing signs and symptoms of SCT and making appropriate referral decisions. The lowest percentage $(1.7 \%, \mathrm{n}=1)$ was seen for 0 out of 9 correct and 9 out of 9 correct. See Table D7 for additional results. Strength and conditioning specialists reported a slightly higher total scenario score $(4.68 \pm 1.73)$ than head football coaches (4.35 \pm 1.81$)$. An Independent Samples t-Test was completed to compare total scenario scores between head football coaches and strength and conditioning specialists. No significant 
differences were evident $(\mathrm{t}=-.656, \mathrm{P}=.699)$ in how the two professionals scored on the scenarios. See Table D8 for additional results.

A One-Way ANOVA was completed to compare total scenario scores between NCAA Divisions, with no significant differences found $\left(\mathrm{F}_{7,41}=.526, \mathrm{P}=.810\right)$ between how the individuals from each division scored on the scenarios. Participants from NCAA Division I FCS represented the highest mean score $(5.12 \pm 1.24)$, while individuals from NCAA Division III represented the lowest mean score $(4.28 \pm 1.41)$. See Table D9 for additional results. These findings suggest moderate situational awareness across the board for both head football coaches and strength and conditioning specialist.

Pearson Correlations

Pearson Correlation tests were run to explore a relationship between how participants rated their confidence level in recognizing signs and symptoms of SCT and total scenario scores. There was a significant, positive correlation found $\left(\mathrm{r}_{1,59}=.258, \mathrm{P}=.05\right)$ (be careful here as even though significant, correlation was low at .258) suggesting that the higher the participants ranked their confidence in recognizing signs and symptoms, the higher they tended to score on the scenarios. See Table D10 for additional results.

\section{DISCUSSION}

Head football coaches and strength and conditioning specialists for NCAA football teams reported on knowledge and awareness of SCT. In general, the majority of individuals reported moderate confidence in recognizing signs and symptoms and making the proper referral decisions in the event of a SCT related episode. The majority of participants also were able to recognize most of the signs and symptoms of SCT when selecting from a list, however no individuals were able to limit their selections to only the correct responses. The majority of head 
football coaches and strength and conditioning specialists were able to identify environmental and/or physical conditions that may predispose an individual with SCT to an adverse event. The vast majority of individuals obtained information about SCT from either a certified athletic trainer or experience with an athlete, suggesting that athletic trainers are attempting to educate coaching staffs on SCT. These findings were consistent with the first hypothesis, that these individuals would not report high levels of knowledge of SCT. Strength and conditioning specialists reported significantly higher confidences levels with regards to signs and symptoms and referral decisions, and also scored higher overall on the scenarios included in the survey, although the scores on the scenarios yielded no significant differences. These findings are consistent with the second hypothesis.

Knowledge of Sickle Cell Trait

No previous research has been conducted studying the knowledge or awareness of SCT among head football coaches and strength and conditioning specialists of any level or sport. It was recommended by Casa et al. ${ }^{15}$ that certified athletic trainers educate coaches about the complications of exertion in athletes that carry SCT. The findings show a trend that suggests this is occurring as the majority of respondents selected certified athletic trainers as a source of obtaining information on SCT. Responses to this question also suggested that football coaches and strength and conditioning specialists are referring to journal articles and experience with athletes in gaining knowledge of SCT. This trend proposes that movements are being made in recognizing SCT and the accompanying complications in athletics. Also adding to this trend is the fact that all except three individuals reported that they had heard of SCT.

Torres-McGehee et al. ${ }^{20}$ and O'Donoghue et al. ${ }^{21}$ researched knowledge of coaches on sport nutrition and sport-related concussions respectively. Torres-McGehee et al. ${ }^{20}$ studied 
collegiate athletes, coaches, athletic trainers, and strength and conditioning specialists, while O’Donoghue et al. ${ }^{21}$ studied high school coaches. Similar to results shown in Torres-McGehee et al., ${ }^{20}$ strength and conditioning specialists reported higher knowledge in this study. These findings were opposite of concussion knowledge studied in O'Donoghue et al., ${ }^{21}$ which reported that coaches had a high level of knowledge. Similar to Torres-McGehee et al., ${ }^{20}$ strength and conditioning specialists in this study were more confident in recognizing signs and symptoms of SCT and in making appropriate referral decisions than head football coaches. When asked to select from a list of pre-disposing environmental and/or physical conditions, the findings were consistent with both Torres-McGehee et al. ${ }^{20}$ and O'Donoghue et al. ${ }^{21}$ The majority of participants selected all three correct responses, which suggested that coaches possess a moderate to high level of knowledge of this medical condition, however strength and conditioning specialists represented the highest percentage.

When evaluating confidence in signs and symptoms between NCAA Divisions, it was found that NCAA Division I FCS and Division I FBS ranked their confidence higher, which is consistent with the third hypothesis that Division I individuals would report higher knowledge levels than those individuals in Division II or III. These findings are consistent with what was expected, most likely due to the required screening that has been in effect since 2010. Perhaps with the recent SCT screening implemented in NCAA Division II, those coaches and strength and conditioning specialists may also report higher knowledge and confidence levels in the near future, and may indicate why they reported higher levels than NCAA Division III.

Through the findings from the knowledge section of the survey, the trends are similar to what was hypothesized. The trends are related to strength and conditioning specialists reporting more knowledge of SCT and more confident and competent in recognizing signs and symptoms 
related to SCT and making appropriate referral decisions, although overall the knowledge levels reported were moderate at best. It is possible that strength and conditioning specialists are more knowledgeable than head football coaches as these individuals are present and mainly responsible for conditioning of most collegiate football teams. Thus, strength and conditioning specialists should be knowledgeable of all medical conditions and emergencies and prepared for every scenario that may come about during a conditioning session. It is also possible that there were more "confident" than "not confident" responses in recognizing signs and symptoms and making appropriate referral decisions as perhaps only individuals who possessed knowledge of SCT completed the survey.

Scenarios

The participants were provided with three scenarios, each followed by a series of questions related to the scenario. The first two scenarios resembled SCT, while the third scenario did not. When evaluating the total scenario scores, findings were similar with both TorresMcGehee et al..$^{20}$ in that the participants showed a moderate amount of knowledge, however strength and conditioning specialists again scored higher overall. When looking at correlations between how the participants' ranked confidence in recognizing signs and symptoms of SCT and how they scored on the scenarios, the findings were significant. This suggests that the higher the rank of confidence in recognizing signs and symptoms of SCT, the higher the individuals scored on the scenarios, consistent with findings of O'Donoghue et al. ${ }^{21}$ Although the correlation was significant relating to high rankings and high scores, the scores were not high overall, similar to the moderate confidence ranking in recognizing signs and symptoms. There were no significant findings when evaluating the total scenario scores between NCAA Divisions. Thus individuals from all NCAA Divisions scored similarly on the scenarios. While the findings were not 
significant, participants from NCAA Division I did score higher overall than individuals from Division II and III. The findings from the scenarios are consistent with the all three hypotheses in that moderate knowledge was reported, strength and conditioning specialists scored higher than head football coaches, and Division I individuals scored higher than Division II and III representatives.

Consistent findings and trends throughout the study suggested that head football coaches and strength and conditioning specialists are becoming knowledgeable about SCT, however the knowledge levels are not where one would expect them to be. Consistent with this are the findings that the majority of participants reported to be moderately confident at best in recognizing signs and symptoms of SCT and making appropriate referral decisions, and that NCAA Division I FBS and FCS ranked higher than individuals in other NCAA Divisions. These findings carried over to the scenarios as moderate to low overall scores were reported. Scores between divisions were also consistent with expectations in that participants from NCAA Division I scored highest, although the differences were not significant. The findings and trends from the scenarios, as the rest of the study, were as expected. However, there is room for vast improvement overall concerning knowledge of SCT in these individuals, especially considering the low to moderate knowledge reported throughout the questionnaire. Not only were the participants not properly educated on SCT, but they also are not highly aware of what to do in the event of an SCT attack. This study was not meant to test whether or not these individuals could diagnose an SCT attack, rather the aim was to gain an understanding as to whether the subject population was able to recognize a potentially deadly situation and make the appropriate decisions needed to possibly save a life. The study suggested that these individuals are not consistently able to do so, meaning more of a focus on education is needed. Athletic trainers, 
similar to what is recommended in Casa et al., ${ }^{15}$ should do a better job of educating coaching staffs on not only SCT, but all medical conditions, as research ${ }^{20,21}$ has shown that certified athletic trainers tend to be more knowledgeable than coaches.

Clinical Implications

The results of this study confirmed that head football coaches and strength and conditioning specialists need more education in order to reduce the risks associated with SCT in athletes. It has been suggested that the majority of deaths in athletics related to SCT have occurred without a certified athletic trainer present. Thus, the proper individuals, head football coaches and strength and conditioning specialists in this case, should be educated properly and thoroughly on SCT. Possible situations in which certified athletic trainers may not be present include player-led practice sessions, conditioning sessions, team walkthroughs, etc. With the chance that head coaches and strength and conditioning specialists are the only professionals present at a team function, this study reported that knowledge levels and awareness are not at the preferred level in order to provide a safe environment for collegiate football players. In order to reduce the risks of complications of SCT and open the possibility to saving the lives of athletes, certified athletic trainers should provide education to these individuals as well as direct them to proper journal articles and professional conferences regarding SCT. While education will not reduce the occurrence or prevalence of SCT, it may help save the lives of athletes who suffer an event from SCT by preparing all individuals necessary who may be present at any team function. According to this study, there is room for improvement in knowledge levels of both professionals. Thus, the clinical implications are that low knowledge levels require more of a focus on educating coaches and strength and conditioning specialists on SCT. 


\section{Limitations}

A primary limitation of this study may be the possibility of a sampling bias of either the head football coaches, strength and conditioning specialists, or a combination of both. Feasibly, a majority of head football coaches or strength and conditioning specialists completed the questionnaire only because they had heard of SCT. Another primary limitation is small sample size. There are individuals who ignored the questionnaire, opted out of the questionnaire, or felt there were no gains if completed. These individuals may have not completed the survey for reasons such as time constraints or work load since the timing of the survey was not optimal. The survey was sent mid and into late march, as spring football season and conditioning practices were most likely beginning. There is also a possibility that the individuals never received the email, as many head football coaches (most notably at larger institutions) have assistants that receive emails for them.

Demographic information was not filled out by every participant in the survey, adding to the limitations. Thus, there were more head football coaches and/or strength and conditioning specialists who completed the survey, but cannot be included in the results, skewing some findings and reducing sample size. The low subject sample size may have directly led to not sufficiently reflecting the characteristics of the overall population of head football coaches and strength and conditioning specialists. In addition, the inclusion criteria that only NCAA head football coaches and strength and conditioning specialists may threaten external validity based on not being able to generalize the findings to all head football coaches and strength and conditioning specialists at all levels. Trends are occurring and this needs to be pursued further to verify the results. 


\section{CONCLUSIONS}

Head football coaches and strength and conditioning specialists for NCAA Division I FCS, I FBS, II, and III football teams reported SCT knowledge levels similar to what was expected and what the literature would suggest. Overall the knowledge of signs and symptoms

was moderate, however both professionals ranked their confidence level in recognizing signs and symptoms as slightly more confident that not. The total scores on the scenarios were moderate to low, suggesting that the participants were less knowledgeable than they perceived they are in recognizing a SCT event. In both areas, knowledge and scenario awareness, strength and conditioning specialists were more confident, knowledgeable, and aware of scenarios than head football coaches, although they reported moderate to low knowledge levels as well. This is also consistent with what was expected, since strength and conditioning specialists are typically involved directly with the conditioning aspect of athletics and may be more aware of exertional conditions than head football coaches. Overall, knowledge levels are lower than they should be in order to provide an optimal environment for NCAA football athletes who carry SCT, and there should be more of a focus placed on education of these individuals on conditions such as SCT. 


\section{REFERENCES}

1. Bautista A. College football's serial murderer: sickle cell trait. Marquette Sports Law Review. 2010;21(1):403-424.

2. Eichner E. Sickle Cell Trait in Sports. Current Sports Med Reports (Amer College Sports Med). 2010;9(6):347-351.

3. Anzalone M, Green V, Maximillian B, Sanchez L, Harrykissoon R, Eichner E. Sickle cell trait and fatal rhabdomyolysis in football training: a case study. Med Sci Sports Exerc. 2009; 42(1): 3-7.

4. Harmon K, Drenzer J, Klossner D, Asif I. Sickle cell trait associated with a rr of death of 37 times in national collegiate athletic association football athletes: a database with 2 million athlete-years as the denominator. Br J Sports Med. 2012; 46: 325-330.

5. Diggs L, Flowers E. High school athletes with the sickle cell trait. J Nat Med Assoc. 1976; 68(6): 492-494.

6. Cleary M, Ruiz D, Eberman L, Mitchell I, Binkley H. Dehydration, cramping, and exertional rhabdomyolysis: a case report with suggestions for recovery. J Sport Rehabil. 2007; 16: 244-259.

7. Anderson S, Eichner R. National Athletic Trainers Association Consensus Statement: Sickle cell trait and the athlete.

8. Bonham V, Dover G, Brody L. Screening student athletes for sickle cell trait — a social and clinical experiment. New England J Med. 2010; 363(11):997-999.

9. Tabor S, Rand S. Sickle cell trait in sports: why the confusion? Athl Ther Today. September 2009;14(5):22-25.

10. Brudvig T, Fitzgerald P. Identification of signs and symptoms of acute exertional rhabdomyolysis in athletes: a guide for the practitioner. Strength Condit J. February 2007; 29(1):10-14.

11. Tarini B, Brooks M, Bundy D. A policy impact analysis of the mandatory NCAA sickle cell trait screening program. Health Services Research. 2012;47(1pt2):446-461.

12. Fidler E. Sickle cell trait: a review and recommendations for training. Strength Cond J. 2012; 34(3): 28-32.

13. Guideline 2R. The student athlete with sickle cell trait. 2012-2013 NCAA Sports Medicine Handbook. 2008; 88-90. 
14. Brown G. New sickle cell trait proposal enters 2013 convention cycle. NCAA News. 2012: 5 .

15. Casa DJ, Guskiewicz KM, Anderson SA, Courson RW, Heck JF, Jimenez CC, McDermott BP, Miller MG, Stearns RL, Swartz EE, Walsh KM. National athletic trainers' association position statement: preventing sudden death in sports. $J$ Athl Train. 2012; 47(1): 96-118.

16. Grundy R, Howard R, Evans J. Practical management of pain in sickling disorders. Archives Disease Child. 1993; 69: 256-259

17. Loosemore M, Walsh S, Morris E, Stewart G, Porter J, Montgomery H. Sudden exertional death in sickle cell trait. Br J Sports Med. 2012; 46: 312-314.

18. Binkley H, Beckett J, Casa D, Kleiner D, Plummer P. National athletic trainers' association position statement: exertional heat illnesses. J Athl Train. 2002; 37(3): 329343

19. Pearson D, Faigenbaum A, Conley M, Kraemer W. The national strength and conditioning association's basic guidelines for the resistance training of athletes. Strength Cond J. 2000; 22(4): 14.

20. Torres-McGehee T, Pritchett K, Zippel D, Minton D, Cellamare A, Sibilia M. Sports nutrition knowledge among collegiate athletes, coaches, athletic trainers, and strength and conditioning specialists. J Athl Train. 2012;47(2):205-211.

21. O'Donoghue E, Onate J, Van Lunen B, Peterson C. Assessment of high school coaches' knowledge of sport-related concussions. Athl Train Sport Health Care: J Practicing Clinician. 2009;1(3):120-132. 


\section{APPENDICES}




\section{APPENDIX A}

\section{THE PROBLEM}

\section{Research Question}

Sickle Cell Trait (SCT) is an emerging topic that has gained recognition over the past several years within the sports arena. It is now known that SCT can be fatal and has been dubbed a "serial killer" among sports. ${ }^{1}$ The first known death of an athlete due to SCT was in 1974, and over the past twelve years, SCT has been determined to be the cause of death in sixteen athletes. It is the leading cause of death in the NCAA, with 16 deaths since the year 2000. Of those sixteen, fifteen of the deaths occurred during sprinting and conditioning, and one while weight lifting. ${ }^{2}$ Over the past eight years alone, SCT has claimed the lives of nine athletes ranging in age from 12-19, including five college football players, two high school athletes (one female basketball player, one football player), and two junior football players. Five percent (seven of 136) of the non-traumatic sports deaths in college and high school athletes over the past decade have been from exertional sickling. ${ }^{7}$ It is estimated that 100 million individuals worldwide carry SCT. Of these 100 million, 2 million are Americans (8\% of all African-American, $0.5 \%$ of all Hispanic-Americans, $0.2 \%$ of all Caucasian-Americans). Therefore, colleges and universities may identify, through screening, an estimated 400-500 new carriers each year. ${ }^{3,8,17}$

Sickle Cell Trait is a genetic condition that occurs when an individual inherits one normal hemoglobin gene and one sickling hemoglobin gene (hemoglobin $S$ ). ${ }^{1,4,7,8,9,17}$ This gene can cause red blood cells to take on a sickling shape during exertion if they become starved of oxygen, this can take place within the range of one to five minutes of full exercise bouts. ${ }^{2,5,7,16}$ This sickling can cause a "logjam" of red blood cells within blood vessels. Typically, a fatal collapse due to SCT is caused by the aforementioned exertional sickling of red blood cells, 
which can lead to ischemic rhabdomyolysis. ${ }^{10}$ Rhabdomyolysis is defined as the rapid breakdown of muscle tissue due to the lack of oxygen reaching the muscle, allowing the contents of the cells to release into the plasma. ${ }^{2,6,10}$ Despite the medical seriousness of the condition, SCT in sports is often misdiagnosed by Certified Athletic Trainers, other healthcare professionals, and/or the strength and conditioning specialist. ${ }^{2}$ Symptoms of a SCT attack often mimic those of exertional heat illness as well as a cardiac issue, such as hypertrophic cardiomyopathy (HCM). ${ }^{2,7,18}$ However, there are ways to differentiate between an attack of SCT and common misdiagnoses. First, an athlete suffering from a SCT attack will not have an elevated core body temperature and will typically present symptoms earlier in the training session, whereas the opposite can be said of both in an athlete who has collapsed due to the heat. Also, an athlete suffering from a heat related illness will experience muscle cramping that cause the muscles to present hardened, whereas a sickling cramp due to exertional rhabdomyolysis will present with weaker muscle cramping. An athlete who is suffering from a cardiac condition will not only exhibit neither cramping nor an elevated body temperature; however, they will not be able to communicate with the healthcare provider. ${ }^{7,10}$

In recent years, the National Collegiate Athletic Association (NCAA) has implemented a SCT screening policy. In 2007, the National Athletic Trainers' Association (NATA) and the College of American Pathologists recommended that institutions consider screening athletes for SCT. ${ }^{8}$ The NCAA screening policy was the result of a law-suit from the family of a college football player who passed away following an attack from SCT resulting in acute exertional rhabdomyolysis. ${ }^{4,8,11}$ At first, the NCAA was reluctant to put a screening policy into place for fear that the policy would demonstrate discrimination by the organization. The policy was long debated before its passing in $2010 .{ }^{11}$ In 2010 , screening for student-athletes became mandatory at 
the Division I level ${ }^{8,11,17}$ and, as of 2012, the Division II level, unless the student-athlete can provide results from a previously administered test. ${ }^{8}$ At the Division III level, administrators and athletics departments are considering similar policies, however, at this time screening for all Division III student-athletes is only recommended, and the individual can refuse a test by signing a waiver if the condition of the athlete is otherwise unknown. ${ }^{8,13}$

Sickle Cell Trait screening is completed in all fifty states in the United States at birth. ${ }^{7,11}$ This information is invaluable to the athlete, the athlete's parents, coaches, and medical staff alike. If the information and results are made known to the athlete, it can provide a gateway to education about SCT. Education is the key factor that can save lives. Not only should athletes be educated and aware of the signs, symptoms, and dangers of SCT, but coaches and strength and conditioning specialists as well. Certified Athletic Trainers (ATCs) should be well aware of the condition from their educational background. However, it is not the ATC who run practice and conditioning sessions. Head Coaches and Certified Strength and Conditioning Specialists who act as strength and conditioning specialists at NCAA Division I, II, and III institutions should also be well aware of SCT. The NATA released a position statement in 2012 focused on sudden death in sports. ${ }^{15}$ Among the topics discussed were SCT and Rhabdomyolysis. The NATA recommended in the position statement ATCs should educate coaches as well as athletes about the complications associated with SCT, and how it can lead to exertional rhabdomyolysis. It was also recommended that athletes who tested positive for the condition be allowed longer rest periods and be excluded from extreme exertional performance testing. ${ }^{15}$ These individuals (Head football coaches and strength and conditioning specialists), along with ATCs, should hold the proper knowledge and awareness of the condition as well as be aware of athletes on their rosters that have tested positive for SCT. 
Head football coaches and strength and conditioning specialists will spend more time overall with the athletes than the ATC. On occasion, there are conditioning sessions and "playerled" practices in which an ATC is not present. It is in this case that a head football coach and/or a strength and conditioning specialist may be responsible for athletes in the event of a sickling attack. Despite the possible contact of a strength and conditioning specialist and/or a football coach with an athlete with SCT, there are no known studies examining the knowledge of head football coaches and strength and conditioning specialists about SCT. Therefore, this subject population should be evaluated. Head football coaches and strength and conditioning specialists at all NCAA Divisions and subdivisions should be knowledgeable and be held accountable for awareness of the seriousness of SCT, as well as know how to act in the event of an attack during exertion. Therefore, the following research questions are being asked:

1. What are the knowledge and awareness levels of head football coaches and strength and conditioning specialists of NCAA Division I (FBS, FCS), Division II, and Division III football teams?

2. Is there a difference in the level of knowledge and awareness of Sickle Cell Trait between head football coaches and strength and conditioning specialists for NCAA Division I (FBS, FCS), Division II, and Division III football teams?

3. Are there differences between NCAA Divisions (I [FBS, FCS], II, III) in the overall level of knowledge of Sickle Cell Trait among head football coaches and strength and conditioning specialists?

4. Where, if applicable, did the head coach or strength and conditioning specialist obtain their information and knowledge of Sickle Cell Trait?

Experimental Hypotheses

1. Based on the responses, the majority of coaches and strength and conditioning specialists will not be educated overall of Sickle Cell Trait.

2. Based on the responses, strength and conditioning specialists will be more knowledgeable of Sickle Cell Trait than head football coaches in all NCAA Divisions. 
3. Based on the responses, Division I FCS and Division I FBS head football coaches and strength and conditioning specialists will be more knowledgeable of Sickle Cell Trait than those individuals in Division II and III.

\section{Assumptions}

1. The questionnaire and survey are reliable and valid.

2. The questionnaire will be returned fully completed, with valid responses.

3. The participants will answer each question honestly and accurately.

4. The participants will have knowledge of SCT.

\section{Delimitations}

1. This study drew participants from a population of Division I FBS, Division I FCS, II, and III football coaches, strength and conditioning specialists, and cannot be generalized to the population as a whole.

2. The results of this study cannot be generalized to other NCAA head coaches (i.e. assistant coaches, coaches of other sports.)

\section{Operational Definitions}

1. Sickle Cell Trait - A genetic condition that occurs when an individual inherits one normal hemoglobin gene and one sickling hemoglobin gene (hemoglobin $S$ ). ${ }^{1,7,8,9}$

2. Exertional Rhabdomyolysis - The rapid break down of muscle tissue due to the lack of oxygen reaching the muscle, allowing the contents of the cells to release into the plasma. $^{2,10}$

3. First responder - Certified Athletic Trainer, head coach, assistant coach, or anyone available and/or qualified to treat medical emergencies ${ }^{7}$

4. Non-fatal - Not resulting in death. ${ }^{15}$

5. Screening - Testing athletes for sickle cell trait during pre-participation physicals. ${ }^{7,13}$

6. Strength and Conditioning Specialist - An individual who has passed the National Strength and Conditioning Association's certification examination. ${ }^{13}$

7. Hemoglobin - oxygen carrying component of red blood cell. ${ }^{20}$ 
8. Sickle Cell Disease - genetic disorder characterized by the inheritance of two hemoglobin S genes. ${ }^{1,7,8,9}$

9. Exertional Sickling - The changing of shape of red blood cells during exertion due to the lack of ability to carry sufficient oxygen. ${ }^{21}$

10. NCAA Division I - Institution required by the NCAA to sponsor a minimum of seven sports for women and seven for men (or eight for women and six for men). Additionally, each sporting season must be represented by a sport of each gender. FBS teams must meet a minimum attendance requirement of 15,000 in actual or paid attendance for each home game. ${ }^{22}$

11. NCAA Division II - Institution required by the NCAA to sponsor a minimum of five sports for women (or six) and five for men (or four). Limits are placed on scholarships awarded by the NCAA. ${ }^{22}$

12. NCAA Division III - Institution required by the NCAA to sponsor a minimum of five sports for women (or six) and five for men (or four). No athletic scholarships are awarded at the Division III level. ${ }^{22}$

Limitations

1. Only utilizing Division I FBS, I FCS, II, and III football coaches and strength and conditioning specialists to survey.

2. Threat to external validity by generalizing the findings toward a certain population, rather than other settings.

3. Threat to external validity based on the choice of participants.

4. Participants may not answer questions honestly in an attempt to answer in the way the researcher would want.

5. The questionnaire used is not a valid questionnaire.

6. The participants may have a biased opinion of SCT.

7. The participants will not be in a controlled setting and therefore may access information to assist them in answering questions.

8. The participants may be in a busy location, not a quiet, calm location.

9. The questions on the questionnaire may be misunderstood. 
Significance of the Study

Sickle Cell Trait (SCT) is becoming more prevalent among athletics. It affects many athletes, most of which are involved with football. In many cases, a person may have no knowledge that they carry the trait unless they are involved in athletics in some way. There have been multiple deaths in athletics that are directly contributable to SCT. Coaches and strength and conditioning specialists should have, at the very least, a solid base of knowledge about the condition, and an awareness of how to relate to an athlete who is positive for the trait. By having a base of knowledge about SCT, coaches and strength and conditioning specialists could possibly save the life of an athlete who is suffering from an attack during a practice or event in which a Certified Athletic Trainer is not present. There is limited information in the literature on SCT as it relates to athletics. In fact, no studies were evident on knowledge or perception of knowledge about the condition among coaches of any level or sport.

The information gained from this study will make known the overall body of knowledge regarding SCT among NCAA Division I, II, and III head football and strength and conditioning specialist. Based on the responses to the survey, the level of knowledge and awareness of SCT among these professionals will be revealed and analyzed. Low levels of knowledge will emphasize the need for further education of these individuals on the condition. Education can be provided through the Certified Athletic Trainer, educational presentations, brochures, courses, and/or professional conferences. Deaths have occurred relating to SCT without a Certified Athletic Trainer present. Therefore, it is imperative that coaches and strength and conditioning specialists be educated and aware of how to properly manage an athlete who is suffering from a medical emergency related to SCT. 


\section{APPENDIX B}

\section{LITERATURE REVIEW}

In recent years, Sickle Cell Trait (SCT) has gained recognition in the sports arena. The condition is characterized by an abnormal inheritance of hemoglobin causing red blood cells to alter in shape when starved of oxygen, such as during extreme exertion. Available literature suggests the prevalence, epidemiology, signs and symptoms, treatment, prevention, and screening of SCT; all of which are discussed in the literature review.

\section{Prevalence}

Sickle cell trait is associated with rhabdomyolysis as the third highest killer among high school and college athletes, and is the leading killer in NCAA Division I football; accounting for $63 \%$ of the deaths, and affecting $3 \%-4 \%$ of Division I football players. ${ }^{2}$ In the past seven years, exertional sickling has caused the deaths of nine athletes, aged $12-19,{ }^{7}$ and ten athletes in the past decade. ${ }^{20}$ Death related to exertional sickling has been noted in sports such as distance running, basketball, and most famously, football. ${ }^{1,2,3,4,5,6,7}$ Multiple studies and reviews have explored SCT in football. There are few studies that examine prevalence directly, however the most indepth was a study performed by Tarini et al in $2011 .^{11}$ This study's purpose was to view the rates of death for sudden death related to Sickle Cell Trait (SCT). The study was performed to examine the rates of sudden death and predict how many athletes can be saved by proper education. The researchers used the most recently available NCAA participation rates (20072008) to estimate the number of NCAA Division I athletes to use as their population. The NCAA separates student-athletes into three categories of sports. They are Championship (men and women), Non-championship (men only), and Emerging (women only). This allowed better categorizing and separating of the population. The article discussed the prevalence of SCT 
among athletes. The highest prevalence was among African-American athletes (1/14), followed by Hispanic athletes (1/183), and then by Caucasian athletes (1/625). In 2007-2008 there were 144,181 Division I athletes (81,073 men, 63,108 women). The researchers used the sport with the most athletes for each gender. Football yielded the most male athletes $(n=25,658)$ and track and field yielded the most female athletes $(n=11,230)$. Of these athletes, it is estimated that two out of twenty-three athletes are positive for SCT (863 in football, 463 in track). Assuming these athletes receive $100 \%$ effective education and communication, the lives of seven student-athletes could be saved over a ten year period.

Over the past several decades, studies have shown that SCT does not limit the participation in sports under high demands. ${ }^{25}$ It has been shown that SCT can be a non-factor in short, single-bout exercises that involve a limited reliance on anaerobic glycolysis. ${ }^{25,26}$ In a study conducted over the course of thirty-nine years (between 1956-1995), Ivory Coast track and field champions portrayed a higher percentage of SCT carriers than the general public. Among the 122 national champions, 34 individuals $(27 . .8 \%)$ were SCT carriers who won a combined 78 national titles and set 37 national records in throwing and jumping events. ${ }^{22,23}$ Also, it has been noted that SCT carriers are more successful in jump-and-reach tests when compared to the nonSCT controls according to Hue's study. ${ }^{25,27}$

A higher cross-sectional surface area of type IIx fibers have been found in SCT carriers ${ }^{28}$ but it is unclear as to what causes this anomaly. ${ }^{25}$ Furthermore, SCT carriers may hold a higher ability to perform well in short, fast running events as opposed to distance events. ${ }^{29}$ This may be related to the higher number of type IIx fibers that are recruited during explosive, single-bout movements. Other studies have shown, however, that SCT carriers hold a lower ability to perform repeated, single-bout, short exercises over a period of time than non-SCT carriers. ${ }^{30}$ 
Carriers rely on a rapid rate of oxygen exchange during repeated exercise.${ }^{31}$ While it seems SCT carriers can perform anaerobic exercise with similar outcomes as non-SCT carriers, the same may not be able to be said about aerobic bouts. ${ }^{25}$ Studies have shown that SCT carriers might have difficulty reaching high levels of performance during activities that require persistent anaerobic uptake. ${ }^{29,32}$ There are no differences between SCT carriers and non-carriers for $\mathrm{VO}_{2 \max }$, even under severe hypoxic conditions. ${ }^{33,34,35,36,37}$ Although no differences were found in the previous studies relating to $\mathrm{VO}_{2 \max }$, Vincent ${ }^{25}$ found a lower cytochrome $\mathrm{C}$ oxidase activity in muscle fibers in individuals with SCT. This could lead to the limited oxidative metabolism and lower aerobic capability. ${ }^{28,31}$

\section{Epidemiology}

Normal hemoglobin $(\mathrm{Hb})$ in adults contains two alpha and two beta chains, which combine to create HbA. Sickle Cell Trait is inherited when one develops a mutation in the sixth amino acid as it creates $\mathrm{HbS}$. This individual will inherit one $\mathrm{HbA}$ gene and one $\mathrm{HbS}$ gene from their parents, which allows both types of hemoglobin to be produced in each red blood cell (RBC). Individuals that carry Sickle Cell Disease (SCD,) not to be confused with SCT, inherit $\mathrm{HbS}$ from both parents and produce no $\mathrm{HbA}$ in their RBCs. ${ }^{25} \mathrm{~A}$ SCT carrier is at risk of exertional sickling during exercise by starving their RBCs of oxygen, causing the RBCs to take on a sickling shape, and clogging within blood vessels.

It has been shown that mechanisms of vaso-occlusion in SCD involve certain factors interacting with one another. These factors include impaired blood rheology, abnormally adherent sickle cells, adherent neutrophils and monocytes, coagulation abnormalities, and endothelial dysfunction. ${ }^{25,38,39,40,41,42}$ Furthermore, when a situation involves vaso-occlusion, RBC deformaility becomes impaired and a crisis can develop. ${ }^{25}$ These factors are also associated 
with occlusion of vessels in those with SCT. There have been studies performed examining these factors during exercise. At rest, SCT carriers have a higher blood viscosity, decreased RBC deformability, increased RBC disaggregation threshold, and increased concentration of an adhesion molecule in the plasma. ${ }^{31,43,44,45,46,47,48}$ Exercise was shown to result in a greater RBC deformability in SCT carriers in late phase recovery. However, when the participants were hydrated adequately the abnormalities were normalized in SCT carriers. ${ }^{45,49}$ Also, exercise resulted in a greater activation of leucocytes and platelets in individuals with SCT. All this considered, there were few differences in the coagulation process found in these studies between SCT carriers and controls. ${ }^{50,51,52,53}$ Other studies indicated that although there is a greater blood viscosity in SCT carriers, serum creatine kinase and lactate dehydrogenase levels were very similar between SCT carriers and controls during exercise. ${ }^{52,54}$ Although there were no differences to note, it was considered that the type and intensity of exercise were not great enough to determine whether or not SCT carriers possess a higher risk of exertional rhabdomyolysis or exertional sickling during exercise than non-SCT carriers. ${ }^{54}$

Other factors have been shown to contribute to increasing the risk of crisis among SCT carriers. Some of these factors are heat and high humidity, dehydration, exercise at altitude, fatigue, illness, lack of sleep, poor conditioning, high intensity exercise, and exercise-induced asthma. ${ }^{46,52,55,56,57,58,59,60,61,62,63,64,65}$ While these factors can exacerbate symptoms of adverse events related to SCT, they are also risk factors for non-SCT carriers, with the exception of high altitude. ${ }^{25}$ A study performed by Chirico ${ }^{66}$ showed that if individuals with SCT were physically trained, the oxidative stress response was lower than sedentary SCT carriers. Therefore, being physically fit as a SCT carrier may place the individual at a lower risk for exercise related death. 
Signs and Symptoms

Presentation of an attack associated with SCT seems to encompass a broad spectrum of signs and symptoms. ${ }^{25}$ These symptoms can vary from as mild as muscle pain to as severe as a collapse. ${ }^{58}$ Presentation will typically culminate during sprinting or high intensity, single-bout exercises. Five NCAA Division I football players who have passed away over the last decade were performing sprints for 5-30 minutes. Four more Division I football players carrying SCT have passed away while performing fast-tempo station drills with little rest between 12-60 minutes. $^{25,58,67}$

A sickling attack and/or collapse can present with symptoms closely associated with other common conditions seen in athletes. There are several differential diagnoses and common misdiagnoses of a sickling attack. These conditions may include cardiac emergency, heat illness, and asthma. ${ }^{12}$ In all cases, an otherwise healthy athlete may become the victim of a sudden collapse that may turn fatal if not treated properly. Differentiation of signs and symptoms between the conditions should be evident for coaches, strength and conditioning specialists, certified athletic trainers. When an athlete is suffering from a sickling collapse, the event will usually occur within the first two to three minutes of vigorous activity. Typically, following an attack, the athlete is able to communicate with the first responder what is happening. The athlete may complain of weak, cramping muscles. However, upon observation and palpation, the muscles will seem normal and neither tight nor cramped. If the athlete has experienced muscle cramping resulting from exertional heat illness, he/she may be able to compare the sickling pain to their previous condition. The athlete will most likely say that the sickling pain is somewhat milder than cramps, due to the ischemic nature. In addition to a weak, cramped feeling, the athlete may complain of left upper quadrant abdominal pain. This pain is due to splenic 
infarction or enlargement, caused by the blockage of blood flow to the spleen and other organs. The athlete may also experience difficulty breathing, due to the lack of oxygen in the blood and cramping of muscles. ${ }^{1,2,7,10,15}$ In order to differentiate between a sickling attack and a heat illness attack, there are several points to consider. The athlete's body temperature will not be abnormally elevated with a sickling attack, whereas with a heat illness attack body temperature may approach 106 degrees (Fahrenheit.) Also, where a sickling attack can occur very quickly $(<5$ minutes,) a heat illness collapse will typically have a much longer onset, and the presentation of other symptoms will arise prior to a collapse. An athlete experiencing a cardiac emergency will experience pain in the chest, neck, jaw, and/or arms, as well as loss of consciousness; whereas with a sickling attack, typically none of the aforementioned signs and symptoms are present. Chest tightness, coughing, wheezing, and shortness of breath will occur with an asthma attack, while a sickling attack may present with mild difficulty breathing at its worst. Table B1 shows signs and symptoms associated with these common differential diagnoses and the variances between them. ${ }^{7,12,15}$

Table B1. Common Differential Diagnoses of a Sickling Attack

\begin{tabular}{lllll}
\hline & ASTHMA & CARDIAC & HEAT & SCT \\
\hline \multirow{2}{*}{ ONSET } & $\begin{array}{l}\text { Gradual onset } \\
\text { Inhaler helps }\end{array}$ & $\begin{array}{l}\text { Prev. hx } \\
\text { Sudden onset }\end{array}$ & $\begin{array}{l}\text { Progress w/ core } \\
\text { temp. } \\
\text { Hours to resolve }\end{array}$ & $\begin{array}{l}\text { Sudden onset } \\
<3 \text { minutes }\end{array}$ \\
& & & Cramping & Communication \\
SIGNS \& & Chest tightness & Chest pain & Muscle Tightness & Muscle weakness \\
SYMPTOMS & Wheezing & LOC & Disorientation & ULQ Pain \\
& SOB & SOB & Nausea/Vomiting & Hard to breathe \\
\hline
\end{tabular}

Key: $\mathrm{SOB}=$ Shortness of breath; ULQ = upper left quadrant, $\mathrm{LOC}=$ Loss of consciousness

A deadly complication of SCT is exertional rhabdomyolysis. Rhabdomyolysis is a rapid breakdown of muscle tissue due to lack of oxygen. ${ }^{2}$ The condition often results from injury or irritation that changes the integrity of the muscle cell membrane allowing the release of the cell 
contents into the plasma. ${ }^{10}$ Severe muscle soreness with loss of range of motion is an early sign of rhabdomyolysis. Initially, if the athlete is not stricken with an acute attack, the condition may mimic symptoms of delayed onset muscle soreness. Figure B1 shows the clinical features and examination results of exertional rhabdomyolysis, and proper referral decisions. ${ }^{7,10,15}$ Significant muscle soreness twenty-four to forty-eight hours following an exercise bout should be investigated. Bilateral swelling and loss of active range of motion should be examined, and if both are present, rhabdomyolysis should be considered. Another cardinal sign of rhabdomyolysis is dark, almost cola-colored, urine. This is due to the excretion of myoglobin in the urine. ${ }^{10}$

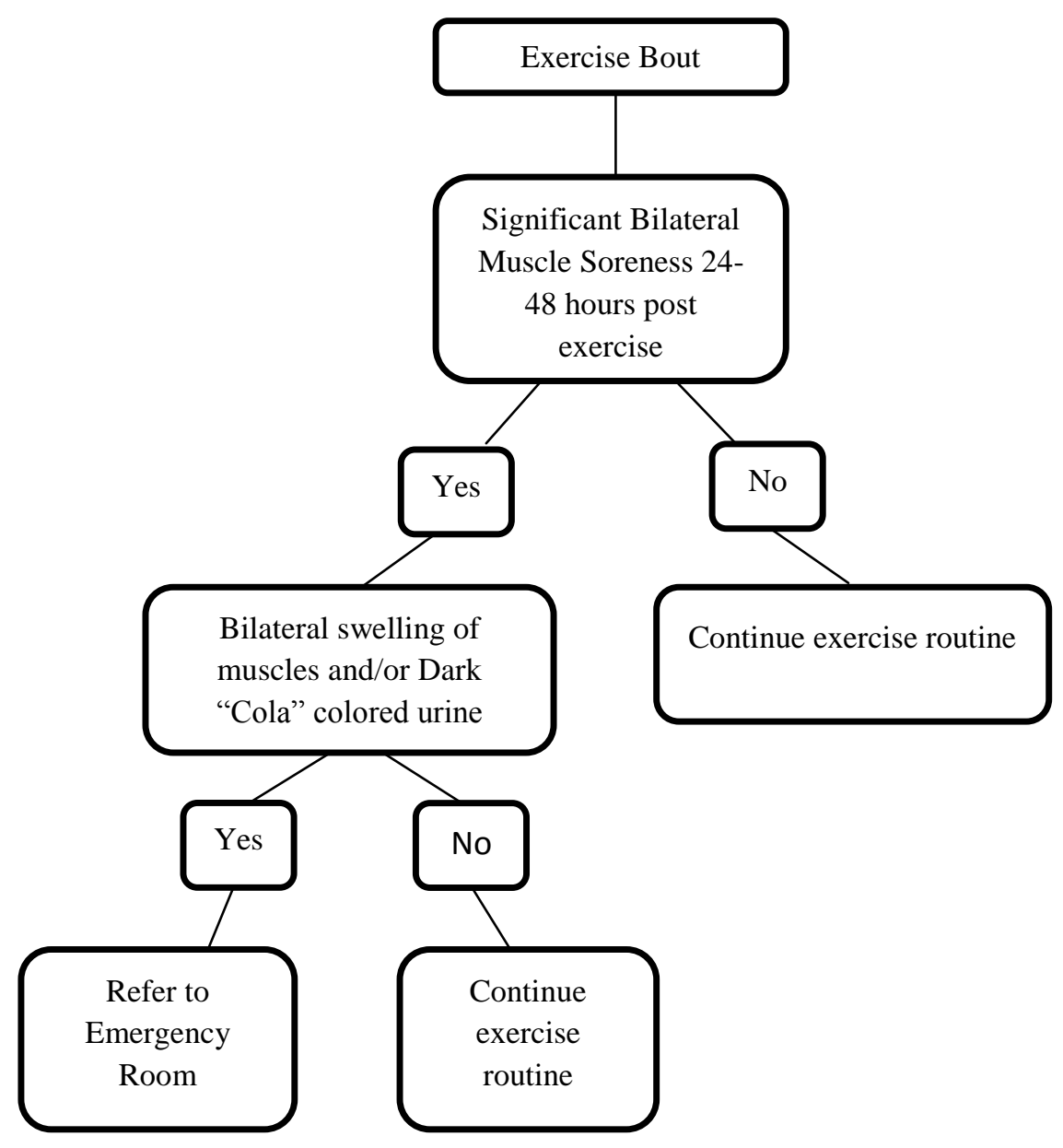


Treatment

Treatment for athletes experiencing a sickling or exertional rhabdomyolysis attack is quite vague according to the research. There is more literature available on prevention of a sickling episode rather than treatment. In the event of a sickling attack resulting in a collapse, the most important treatment protocol is to know the athlete's status relating to SCT. Any muscle pain and/or cramping during or not during an attack should be noted and assumed as a result of SCT. It is important that it be treated as a medical emergency immediately. A first responder should check vital signs, administer high-flow oxygen (15lpm with a non-rebreather mask) if available, get the athlete in a cool environment, initiate the emergency action plan by activating EMS if vital signs worsen (indicative of rhabdomyolysis), and expect explosive exertional rhabdomyolysis. Cessation of activity should occur with the onset of any symptom related to SCT, so as to reduce the likelihood of further complication and/or increase the likelihood the condition will resolve. These signs and symptoms may include muscle cramping, muscle pain, muscle weakness, muscle swelling, tenderness, difficulty breathing due to pain, and/or fatigue. A patient who's condition worsens and is thought to be experiencing explosive exertional rhabdomyolysis should be transported via EMS to the hospital in order to receive immediate intravenous (IV) fluids (1.5 L/hr) to replace fluids in the body in an attempt to prevent renal failure. ${ }^{7,16}$ Cytokine and blood levels within the urine will be tested, as well as ultrasonography to assess the activity of the spleen for inspection and evaluation of rhabdomyolysis. Patients suffering from exertional rhabdomyolysis may be required to remain on IV fluids for a minimum 24-48 hours, until circulation and blood pressure are stabilized. It is possible, if the rhabdomyolysis is severe enough, for patients to spend months in the hospital and on dialysis, and might possibly not return to play. Once the athlete has been treated and released, return to play is possible. A progressive rehabilitation program has been suggested in order to ensure the 
athlete's skeletal muscles are prepared for activity once again. ${ }^{6}$ It is recommended by multiple authors $^{2,12,15}$ to employ a program of one or two weeks and/or up to 15 weeks to ensure full activity readiness. It is recommended early in recovery that the athlete undergo aquatic therapy to reduce eccentric loading on the skeletal muscles. Transitioning from the aquatic rehabilitation, the athlete should partake in light, gradual progression into weight training. Increases in load are recommended once the athlete can complete the suggested sets and repetitions without pain or fatigue. ${ }^{6}$ If an athlete suffers from non-fatal sickling alone, and it is recognized and treated accordingly and appropriately, he/she may return to sport the same day. Patients who experience mild bouts of rhabdomyolysis or myalgia may need to be placed on a rehabilitation program as mentioned previously. ${ }^{15}$

\section{Prevention}

There are currently no evidence-based or best practice guidelines for management or prevention of adverse events related to SCT. The literature provides extended lists from a variety of authors and organizations of possible preventative measures in order to ensure safety of student-athletes with SCT. These recommendations for preventative precautions are fairly similar across the literature. Table B2 provides a list of general preventative measures that have been adopted and combined from different sources. ${ }^{2,7,9,12,13,14,15,25,68,69}$

Table B2. Recommendations for Prevention of Adverse Events Related to Sickle Cell Trait

- $\quad$ Required screening of all student-athletes

- Education of student-athletes, parents, and coaches

- Allow athletes to set their own pace

- Acclimatization to environmental and physical conditions

- Emphasis on hydration

- Cease activity once symptoms are noticed

It is recommended that all student-athletes be aware of their SCT status. Screening is required for NCAA Division I and Division II institutions, and is recommended at Division III 
schools. $^{12,13,14,25}$ The idea of requiring confirmation of SCT status for all student-athletes has met resistance from a multitude of organizations, however, many authors believe it is the first line of prevention. $^{12,14,25,68,69}$ The education of coaches, student-athletes, and parents has also been recommended throughout the literature..$^{9,12,15}$ These individuals may be educated through educational presentations, brochures, courses, professional conferences, and/or Certified Athletic Trainers. Another recommendation put forth by the literature is allowing athletes who are carriers of SCT more recovery time and rest between sets and/or repetition during intense exercise bouts. These athletes should set their own pace during exercise. This will allow the athlete's muscles time for relaxation and hydration, as well as promote heathy circulation. ${ }^{2,7,9,12,15}$ Strength and conditioning specialists and head football coaches should work together with ATCs in order to modify or alter exercise routines for individuals who carry SCT. Proper acclimatization to environmental or physical conditions should be allowed for not only carriers of SCT, but all athletes alike. Athletes should be allotted adequate time to acclimatize to conditions such as extreme heat, cold, and high altitude. This can be accomplished through yearround periodization strength and conditioning programs with slow progression. ${ }^{2,7,9,12,13}$ There should be an emphasis on hydration among all athletes, especially those who carry SCT. Dehydration poses a grave risk, and can lead to complications such as exertional rhabdomyolysis in SCT carriers. ${ }^{9,12}$ Finally, athletes should be encouraged to cease activity once any symptoms consistent with an event related to SCT should arise. If a sickling episode can be identified and treated appropriately and early in the progression, the athlete may escape further complications. ${ }^{2,9,12}$ It must be noted that these are only recommendations, and there are no current evidence-based guidelines in place to prevent or manage an attack related to SCT. 
Screening

Screening for SCT is completed universally across all fifty states of the United States among all newborn children ${ }^{7,11,25}$ Research has shown that early identification and education of a newborn's SCT carrying status lowers the mortality rate of incidents related to SCT when compared to those who were diagnosed later in life. ${ }^{68}$ The NCAA has met resistance against the current policies relating to the requirement of SCT status confirmation prior to athletic participation. ${ }^{7,11,25,69}$ Organizations that have shown resistance to the NCAA's policies include the American Society of Hematology (ASH), the American Society of Pediatric Hematology/Oncology (ASPHO), American Public Health Association (APHA), American Society of Clinical Pathology (ASCP), the United States Department of Health and Human Services Secretary's Advisory Committee on Heritable Disorders of Newborns and Children, and even the Sickle Cell Disease Association of America (SCDAA). ${ }^{25,69}$ The Advisory Committee on Heritable Disorders of Newborns and Children believes individuals should be informed but feels as though the information should remain private and not be required for athletic participation. ${ }^{25,70}$ The American Society of Hematology supports and recommends the implementation of universal preventative measures and precautions in order to reduce exertion-related injuries and deaths, however is against requiring athletes to disclose their SCT carrying status before they may compete in collegiate athletics. ${ }^{69}$ The aforementioned organizations all support the idea that the NCAA policy presents risk of potential harm to the student athlete and the entire population of SCT carriers by, among other things, leading to racial or genetic discrimination. ${ }^{25,69}$ The ASH personally believes that screening policies cannot be justified by current evidence provided by recent research suggesting the danger and relevance of SCT in athletics. ${ }^{25}$ 
The NCAA policy of screening athletes differs among Divisions. ${ }^{11,14}$ Currently, confirmation student athletes' SCT carrying status is required in both Division I (FBS, FCS) and Division II. ${ }^{7,11,13,14}$ In 2010, the NCAA implemented the policy first in Division I institutions. The policy states that all first year athletes (freshmen or transfer) must have their SCT carrying status confirmed prior to athletic competition. Confirmation can be made via a blood solubility test provided at the institution or a primary care physician, or by presenting the institution with previous results from a blood solubility test indicating the status. ${ }^{11,14}$ The policy implemented at the Division II level states that all student athletes, regardless of class status, be required to confirm SCT carrying status prior to athletic competition. ${ }^{14}$ Division III has yet to implement a screening requirement policy, however, it has been brought up in current meetings and is set to be implemented within a short period of time. ${ }^{14}$ Currently, Division III institutions recommend athletes be tested, however, they do not require it of the athletes, and a waiver may be signed to avoid testing or education. ${ }^{11,13,14}$ The proposed Division III policy will provide a sort of "middle ground" between the policies of Division I and Division II. In the first year of the proposed policy, Division III institutions would require confirmation from first year athletes (freshmen and transfer), then would require confirmation from all student-athletes after the first year. ${ }^{14}$ Despite heavy resistance from multiple organizations, the NCAA continues to press forward with screening programs.

\section{Coaches' Knowledge of Medical Conditions}

There have been few studies performed studying knowledge of medical conditions among coaches of any sport at any level. Two studies ${ }^{20,21}$ in particular were reviewed and used in this study in an attempt to create expectations of knowledge levels among coaches. One study performed by Torres-McGehee et al. ${ }^{20}$ studied knowledge of sports nutrition among collegiate 
athletes, coaches, athletic trainers, and strength and conditioning specialists. The questionnaire used consisted of a demographic section and a knowledge of sports nutrition section. TorresMcGehee et al. ${ }^{20}$ suggested all individuals that were assessed had just below-average knowledge on sports nutrition. Within the individuals, athletic trainers and strength and conditioning specialists showed higher knowledge levels than coaches.

O’Donoghue et al. ${ }^{21}$ performed a study in 2009 assessing high school coaches' knowledge of sport-related concussions. Again a survey was created to assess demographics and knowledge of this particular medical condition. This study revealed coaches possessed a high level of knowledge concerning sport-related concussion, especially when the individuals had a personal history of concussion. Also found in this study was that discussion with a certified athletic trainer yielded no significant results regarding knowledge scores. This suggests that there is a possibility certified athletic trainers do not educate coaches enough as recommended by Casa et al. ${ }^{15}$

Summary

Sickle Cell Trait has been determined the cause of several deaths related to exertion during athletics. There have been sixteen documented deaths in collegiate athletics in the past twelve years related to SCT. Recognition is growing among athletics, as it has been suggested that two out of every twenty-three athletes participating in collegiate football and collegiate women's track and field are positive carriers of SCT. The condition is inherited when an individual collects one normal hemoglobin gene and one sickling hemoglobin gene from their parents. This abnormality leads to complications during exercise by altering the shape of red blood cells as they become deprived of oxygen, leading to red blood cells collecting within the vessels which will starve muscles of oxygen. Events related to the condition will present with 
signs and symptoms similar to other exertional conditions including heat illness, asthma, and cardiac distress. Presentation of symptoms can occur as quickly as 3-5 minutes into an exertional bout. Differences between signs and symptoms of SCT and other conditions. Treatment and prevention of the condition go hand-in-hand, as the best treatment is prevention. Different organizations and authors have suggested prevention strategies related to SCT in athletics. Screening for the condition is done at birth in all 50 states, and is now a requirement among all NCAA Divisions as a preventative measure. Based on research ${ }^{20,21}$ head football coaches and strength and conditioning specialists may or may not have knowledge of SCT, however, strength and conditioning coaches may have higher knowledge than head football coaches. 


\section{APPENDIX C}

\section{ADDITIONAL METHODS}

TABLE C1. Initial Cover Letter to Head Football Coaches and Strength and Conditioning Specialists

Date

Dear Head Football Coach or Strength and Conditioning Specialist,

This message is being sent as a request to participate in a research study being conducted by the primary investigator (PI) Michelle A. Sandrey PhD, ATC and Co-PI Timothy D. Yates ATC, a Graduate Athletic Training Student. Both investigators are affiliated with West Virginia University. Participation will require you to answer a 33 question survey. The purpose of this study is to determine the level of knowledge and awareness of Sickle Cell Trait among head football coaches and strength and conditioning specialists at the NCAA Division I FBS, Division I FCS, Division II, and Division III levels. This thesis is being completed to partially fulfill requirements for the completion of a Master of Science Degree in Athletic Training at West Virginia University.

The following survey includes 33 multiple choice, single answers, and scenario questions on demographics and knowledge of Sickle Cell Trait. You are not required to answer all the questions. You may withdraw from the study at any time with no penalty. The survey should take approximately 10 minutes to complete. Please follow this link to complete the survey: $<$ link $>$

Your involvement in this survey will be kept anonymous throughout the entirety of the study. You will not be required to include your name on the survey; and none of the information will be presented in such a way to allow individual participants to be identified. You may withdraw from the study at any time with no penalty.

I would like to respectfully request that you participate in this study, as it could be beneficial in examining the knowledge and awareness of a serious medical condition and advocating or disputing the need for education that could save the lives of collegiate athletes. Thank you so much for your time. If you should have any questions regarding this email, survey, and/or the study itself, please feel free to contact me David Yates ATC at (304)546-9231 and/or tyates5@mix.wvu.edu or Dr. Michelle A. Sandrey at (304)293-3295 ext 5220 and/or msandrey@mail.wvu.edu.

Thank you in advance for your participation in this study.

Sincerely,

Timothy D. Yates, ATC

West Virginia University Institutional Review Board Acknowledgement of this study is on file. 
TABLE C2. Questionnaire to Head Football Coaches and Strength and Conditioning Specialists

\section{KNOWLEDGE OF SICKLE CELL TRAIT}

1. Have you ever heard of the condition known as Sickle Cell Trait?
○ Yes
○ No
- I'm Not Sure

2. How/where did you obtain your knowledge of Sickle Cell Trait? (check all that apply)
- College course
- Educational presentation
- Your athletic trainer
- Professional conference
- NCAA Sports Medicine Handbook
- Journal articles
- Experience with an athlete
o Other

3. Please rate your familiarity with the following conditions from least to most familiar? ( 0 being not familiar, 4 being very familiar)

$\begin{array}{lrlll} & \text { Not at all } & & & \text { Very } \\ \text { Sickle Cell Trait } & 1 & 2 & 3 & 4 \\ \text { Exercise-Induced Asthma } & 1 & 2 & 3 & 4 \\ \text { Sudden Cardiac Death } & 1 & 2 & 3 & 4 \\ \text { Exertional Heat Illness } & 1 & 2 & 3 & 4\end{array}$

4. How confident do you feel in recognizing the signs and symptoms of an attack caused by Sickle Cell Trait?

$\begin{array}{llllllllllll}\text { Not confident } & 1 & 2 & 3 & 4 & 5 & 6 & 7 & 8 & 9 & 10 & \text { Very confident }\end{array}$

5. How confident are you in your ability to make the proper decisions/referral in the event of a collapse caused by Sickle Cell Trait?

$\begin{array}{llllllllllll}\text { Not confident } & 1 & 2 & 3 & 4 & 5 & 6 & 7 & 8 & 9 & 10 & \text { Very confident }\end{array}$

6. Please rate your familiarity with the return to play guidelines, published by the NATA in the Position Statement "Preventing Sudden Death in Athletes", for an individual who has suffered an event related to Sickle Cell Trait?

$\begin{array}{llllllllllll}\text { Not familiar } & 1 & 2 & 3 & 4 & 5 & 6 & 7 & 8 & 9 & 10 & \text { Very familiar }\end{array}$

7. From the signs and symptoms listed below, which are most commonly associated with an event related to Sickle Cell Trait? (check all that apply

- Gradual onset

- Muscle cramping

- Headache

- Acute swelling of joints

$\circ$ Pain in the right arm

- Abdominal pain

- Flushed skin 
Profuse sweating

- Sudden collapse

- Convulsions

- Dry skin

- Muscle weakness

- Loss of consciousness

- Vomiting

- Elevated body temperature

8. Which of the following physical or environmental conditions can predispose a carrier of Sickle Cell Trait to an adverse event? (check all that apply)

- Exercising in the heat

- Exercising in the morning

- Exercising at night

- Exercising in the cold

- Exercising in high altitude

- Exercising while not properly hydrated

\section{SCENARIO SECTION}

\section{SCENARIO ONE}

During a pre-season football practice, an athlete removes himself from practice after only 25 minutes complaining of weak muscles, the feeling of cramped muscles, and shortness of breath. You check with him and he tells you this has never happened before but he feels as though he can play through it. There is no Certified Athletic Trainer present. Please answer the questions below based on this scenario.

9. Does the scenario above resemble an event that could possibly be related to Sickle Cell Trait?
○ Yes
- No
- I'm not sure

10. Which signs or symptoms help you conclude this incident is related to Sickle Cell Trait? (check all that apply)

- Muscles seem to be cramping

- It is a pre-season practice

- The athlete has only been exercising for a short time

- He has shortness of breath

11. What would you do next?

- Remove the athlete from practice, and allow him to rest and hydrate

- Let him make the decision whether to practice himself

- Tell him to return to his drill

- There is nothing you can do, call the Certified Athletic Trainer

12. Please rate how important you would consider the athlete's Sickle Cell Trait carrying status (Positive or Negative) to be in this case?

1

Not at all important
2 3
4

Very important 
13. How comfortable would you feel in appropriately treating this athlete?

$\begin{array}{cccccccccc}1 & 2 & 3 & 4 & 5 & 6 & 7 & 8 & 9 & \begin{array}{c}10 \\ \text { Very comfortable }\end{array}\end{array}$

\section{SCENARIO TWO}

An athlete during a mid-season football practice collapses within the first 3 minutes of wind sprints. He is able to communicate with you and says it feels like his muscles are cramping. However, when you look at his muscles, they do not appear to be cramped. His body temperature is normal, however his pain and the feeling of cramping is increasing. He has pain in his upper left abdomen, and is complaining of shortness of breath. The Certified Athletic Trainer is not present. Please answer the questions below based on this scenario

14. Does the scenario above resemble an event related to Sickle Cell Trait
O Yes
○ No
○ I'm not sure

15. Which signs and symptoms help you conclude this incident is related to Sickle Cell Trait? (check all that apply)
○ He is able to communicate
- He has shortness of breath
- His muscles seem to be cramping
- His body temperature is not elevated

16. What would you do next?

o Call 911

- Let the athlete rest to see if symptoms resolve

- Tell the athlete to get back up and finish his sprints

○ Rapidly cool the athlete

17. Please rate how important you would consider the athlete's Sickle Cell Trait carrying status (Positive or Negative) to be in this case?

1

Not at all
2$$
3
$$

34

18. How comfortable would you feel in appropriately treating this athlete?

$\begin{array}{cccccccccc}1 & 2 & 3 & 4 & 5 & 6 & 7 & 8 & 9 & 10 \\ \text { at all } & & & & & & & & & \\ \text { Very comfortable }\end{array}$

\section{SCENARIO THREE}

An athlete reports to you during practice following a series of wind sprints. He is unable to catch his breath and is wheezing loudly. He is breathing very rapidly and shallow, and is complaining of tightness in his chest. You notice the athlete's lips and finger tips appear to be blue in color. The Certified Athletic Trainer is not present. Please answer the questions below based on this scenario. 
19. Does this scenario represent an event related to Sickle Cell Trait?
○ Yes
○ No
○ I'm not sure

20. What signs and symptoms help you conclude the incident is related to Sickle Cell Trait? (check all that apply)
- Body temperature
- Shortness of breath
o Cooughing
○ Wheezing

21. What would you do next?

- Remove the athlete from practice, and help him control his breathing

- Let him return to his drill

- Remove the athlete from practice, and rapidly cool his body

- There is nothing you can do, call the Certified Athletic Trainer

22. Please rate how important you would consider the athlete's Sickle Cell Trait carrying status (Positive or Negative) to be in this case?

1

Not at all
2
34

Very important

23. How comfortable would you feel in appropriately treating this athlete?

$\begin{array}{lllllllll}1 & 2 & 3 & 4 & 5 & 6 & 7 & 8 & 9 \\ \begin{array}{c}10 \\ \text { Very comfortable }\end{array}\end{array}$

\section{DEMOGRAPHICS}

24. For what NCAA Division are you currently employed?
- Division I FCS
- Division I FBS
- Division II
○ Division III

25. What is your gender?
- Male
○ Female
- Prefer not to answer

26. What is your position title?
- Head football coach
- Head strength and conditioning specialist
o Other

27. How many years have you been working as a coach or Strength and Conditioning coach? 
28. How many years have you held your current position?

29. What is the highest degree you hold?

Select only one

- Associate Degree

- Bachelor's Degree

- Master's Degree

- Doctoral Degree

o Other

30. What additional certifications do you hold?
o None
- CSCS
- NASMPES
- CES
O Other

31. What is the approximate number of athletes on your football team?

32. Are you a positive carrier of Sickle Cell Trait?
O Yes
○ No
- I'm not sure

33. Have you ever come in contact with an athlete who was a positive carrier of Sickle Cell Trait?
○ Yes
O No
○ I'm not sure 
TABLE C3. Follow-up Cover Letter to Head Football Coaches and Strength and Conditioning Specialists

\section{Date}

Dear Head Football Coach or Strength and Conditioning Specialist,

This message is being sent as a request to participate in a research study being conducted by the primary investigator (PI) Michelle A. Sandrey PhD, ATC and Co-PI Timothy D. Yates ATC, a Graduate Athletic Training Student. Both investigators are affiliated with West Virginia University. Participation will require you to answer a 33 question survey. The purpose of this study is to determine the level of knowledge and awareness of Sickle Cell Trait among head football coaches and strength and conditioning specialists at the NCAA Division I FBS, Division I FCS, Division II, and Division III levels. This thesis is being completed to partially fulfill requirements for the completion of a Master of Science Degree in Athletic Training at West Virginia University.

The following survey includes 33 multiple choice, single answers, and scenario questions on demographics and knowledge of Sickle Cell Trait. You are not required to answer all the questions. You may withdraw from the study at any time with no penalty. The survey should take approximately 10 minutes to complete. Please follow this link to complete the survey: $<$ link>

Your involvement in this survey will be kept anonymous throughout the entirety of the study. You will not be required to include your name on the survey; and none of the information will be presented in such a way to allow individual participants to be identified. You may withdraw from the study at any time with no penalty.

I would like to respectfully request that you participate in this study, as it could be beneficial in examining the knowledge and awareness of a serious medical condition and advocating or disputing the need for education that could save the lives of collegiate athletes. Thank you so much for your time. If you should have any questions regarding this email, survey, and/or the study itself, please feel free to contact me David Yates ATC at (304)546-9231 and/or tyates5@mix.wvu.edu or Dr. Michelle A. Sandrey at (304)293-3295 ext 5220 and/or msandrey@mail.wvu.edu. This is a follow-up email to let you know there is still time to fill out the survey. Thank you, as this is just a reminder email.

Thank you in advance for your participation in this study. Sincerely,

Timothy D. Yates, ATC

West Virginia University Institutional Review Board Acknowledgement of this study is on file. 


\section{APPENDIX D}

\section{ADDITIONAL RESULTS}

Table D1. NCAA Division of Employment and Position Title

\begin{tabular}{lll}
\hline Division/Position & Percent & $\mathrm{n}$ \\
\hline NCAA Division I FCS & $16.3 \%$ & 8 \\
NCAA Division I FBS & $14.3 \%$ & 7 \\
NCAA Division II & $26.5 \%$ & 13 \\
NCAA Division III & $29.6 \%$ & 21 \\
Head Football Coach & $40.8 \%$ & 20 \\
Strength and Conditioning Specialist & $59.2 \%$ & 29 \\
\hline
\end{tabular}

Table D2. Where Knowledge of Sickle Cell Trait was Obtained

\begin{tabular}{lll} 
Source & Percent & $\mathrm{n}$ \\
\hline Certified Athletic Trainer & $67.8 \%$ & 40 \\
Experience With an Athlete & $47.5 \%$ & 28 \\
College Course & $39.0 \%$ & 23 \\
Journal Articles & $33.9 \%$ & 20 \\
Professional Conference & $30.5 \%$ & 18 \\
Educational Presentation & $27.1 \%$ & 16 \\
NCAA Sports Med & & 6 \\
Handbook & $10.2 \%$ & 6 \\
\hline
\end{tabular}

Table D3. Signs and Symptoms That May Associate with Sickle Cell Trait

\begin{tabular}{lll}
\hline Sign/Symptom & Percent & $\mathrm{n}$ \\
\hline Muscle Weakness* & $72.9 \%$ & 43 \\
Sensation of Cramping Muscles* & $64.4 \%$ & 38 \\
Sudden Collapse* & $50.8 \%$ & 30 \\
Elevated Body Temperature & $35.6 \%$ & 21 \\
Flushed Skin & $33.9 \%$ & 20 \\
Loss of Consciousness & $30.5 \%$ & 18 \\
Gradual Onset of Symptoms & $28.8 \%$ & 17 \\
Abdominal Pain* & $22.0 \%$ & 13 \\
Headache & $22.0 \%$ & 13 \\
Acute Swelling of Joints & $20.3 \%$ & 12 \\
Profuse Sweating & $18.6 \%$ & 11 \\
Dry Skin & $10.2 \%$ & 6 \\
Convulsions & $10.2 \%$ & 6 \\
Vomiting & $10.2 \%$ & 6
\end{tabular}


Pain in Right Arm

KEY: * denotes correct response

Table D4. Environmental Conditions that May Predispose Sickle Cell Trait Attack

\begin{tabular}{lll}
\hline Condition & Percent & $\mathrm{n}$ \\
\hline Exercising in the Heat* & $80.0 \%$ & 48 \\
Exercising While Not Hydrated* & $75.0 \%$ & 45 \\
Exercising at High Altitude* & $63.3 \%$ & 38 \\
Exercising in the Morning & $16.7 \%$ & 10 \\
Exercising in the Cold & $6.7 \%$ & 4 \\
Exercising at Night & $6.7 \%$ & 4 \\
\hline
\end{tabular}

$\mathrm{KEY}$ : denotes correct response

Table D5. Comparison of Confidence with Signs/Symptoms and Referral and T Values

\begin{tabular}{lllll}
\hline Confidence Variable & Professional & Mean and SD & T Value & P Value \\
\hline \multirow{2}{*}{ Signs/Symptoms } & FC & $3.85 \pm 2.815$ & $\mathrm{t}=-3.372$ & $\mathrm{P}=.002^{*}$ \\
& S\&C & $6.50 \pm 2.589$ & & \\
& & & & \\
Referral & FC & $4.40 \pm 2.998$ & $\mathrm{t}=-2.949$ & $\mathrm{P}=.005^{*}$ \\
\hline
\end{tabular}

KEY: * significant finding at $\mathrm{P}<.05$ level, $\mathrm{FC}=$ Football Coach, $\mathrm{S} \& \mathrm{C}=$ Strength and Conditioning Coach

Table D6. Tukey HSD Comparison of Confidence in Signs and Symptoms Between NCAA Divisions

\begin{tabular}{|c|c|c|c|c|}
\hline Division & Mean and SD & Comparing to & Tukey & P Value \\
\hline \multirow[t]{3}{*}{ Div. I FBS } & $8.00 \pm 1.673$ & Div. I FCS & 0.375 & $\mathrm{P}=.993$ \\
\hline & & Div. II & $3.462 *$ & $\mathrm{P}=.048^{*}$ \\
\hline & & III & $3.667 *$ & $\mathrm{P}=.020 *$ \\
\hline \multirow[t]{3}{*}{ Div. I FCS } & $7.63 \pm 1.923$ & Div. I FBS & -0.375 & $\mathrm{P}=.993$ \\
\hline & & Div. II & 3.087 & $\mathrm{P}=.055$ \\
\hline & & III & $3.292 *$ & $\mathrm{P}=.020 *$ \\
\hline \multirow[t]{3}{*}{ Div. II } & $4.54 \pm 2.537$ & Div. I FBS & -3.462 & $\mathrm{P}=.048 *$ \\
\hline & & Div. I FCS & -3.087 & $\mathrm{P}=.055$ \\
\hline & & Div. III & 0.205 & $\mathrm{P}=.996$ \\
\hline \multirow[t]{3}{*}{ Div. III } & $4.33 \pm 3.022$ & Div. I FBS & -3.667 & $\mathrm{P}=.020^{*}$ \\
\hline & & Div. I FCS & -3.292 & $\mathrm{P}=.020^{*}$ \\
\hline & & Div. II & -0.205 & $\mathrm{P}=.996$ \\
\hline
\end{tabular}

$\mathrm{KEY}: *$ denotes significance at $\mathrm{P}<.05$ level 
Table D7. Total Scenario Scores

\begin{tabular}{lll} 
Score & Percent & $\mathrm{n}$ \\
\hline 0 out of 9 correct & $1.7 \%$ & 1 \\
1 out of 9 correct & $13.3 \%$ & 8 \\
2 out of 9 correct & $5.0 \%$ & 3 \\
3 out of 9 correct & $8.3 \%$ & 5 \\
4 out of 9 correct & $18.3 \%$ & 11 \\
5 out of 9 correct & $23.3 \%$ & 14 \\
6 out of 9 correct & $15.0 \%$ & 9 \\
7 out of 9 correct & $13.3 \%$ & 8 \\
8 out of 9 correct & $0.0 \%$ & 0 \\
9 out of 9 correct & $1.7 \%$ & 1 \\
\hline
\end{tabular}

Table D8. Comparison of Scenario Scores Between Professionals, t Value

\begin{tabular}{llll}
\hline Professional & Mean and SD & $\mathrm{t}$ Value & $\mathrm{P}$ Value \\
\hline Football Coach & $4.35 \pm 1.81$ & $\mathrm{t}=-.656$ & $\mathrm{P}=.699$ \\
Strength and Conditioning & $4.68 \pm 1.73$ & & \\
\hline
\end{tabular}

Table D9. ANOVA Comparison of Scenario Scores Between Divisions

\begin{tabular}{lllll}
\hline Division & Mean and SD & Comparing to & Mean Difference & $\mathrm{P}$ Value \\
\hline Div. I FBS & $4.29 \pm 2.49$ & Div. I FCS & -0.839 & $\mathrm{P}=.80$ \\
& & Div. II & -0.483 & $\mathrm{P}=.938$ \\
& Div. III & -0.010 & $\mathrm{P}=1.00$ \\
Div. I FCS & $5.12 \pm 1.24$ & Div. I FBS & 0.839 & \\
& & Div. II & 0.355 & $\mathrm{P}=.80$ \\
& & Div. III & 0.840 & $\mathrm{P}=.970$ \\
& & & $\mathrm{P}=.671$ \\
Div. II & $4.76 \pm 2.12$ & Div. I FBS & 0.483 & \\
& & Div. I FCS & -0.355 & $\mathrm{P}=.938$ \\
& & Div. III & 0.484 & $\mathrm{P}=.970$ \\
& & & $\mathrm{P}=.868$ \\
Div. III & $4.28 \pm 1.41$ & Div. I FBS & 0.010 & \\
& & Div. I FCS & -0.840 & $\mathrm{P}=.100$ \\
& & Div. II & -0.484 & $\mathrm{P}=.671$ \\
& & & $\mathrm{P}=.868$ \\
\hline
\end{tabular}


Table D10. Pearson Correlation Between Confidence in Signs and Symptoms and Scenario Score

Confidence Rank Mean and SD

$5.37 \pm 3.13$

KEY: * denotes significance at $\mathrm{P}<.05$ level
Scenario Score Mean and SD

$4.36 \pm 2.03$ $r$ Value

$\mathrm{r}=.258$
$P$ Value

$\mathrm{P}=.05^{*}$ 


\section{APPENDIX E \\ RECOMMENDATIONS FOR FUTURE RESEARCH}

1. A recommendation is to repeat the study over a longer period of time, as to collect more responses, raising the sample size and possibly the significance

2. Another recommendation is to include certified athletic trainers in the study to survey on how knowledgeable they perceive the head football coaches or strength and conditioning specialists to be

3. Another recommendation is to include head football coaches and strength and conditioning specialists from other levels (i.e. NAIA, Junior College) in order to better generalize to the population, raising external validity

4. A final recommendation is to provide an educational aspect (i.e. flyer) following completion of the survey to further advocate for the education of head football coaches and strength and conditioning specialists 


\section{ADDITIONAL REFERENCES}

22. Quintó L, Aponte J, Alonso P, et al. Relationship between haemoglobin and haematocrit in the definition of anaemia. Tropical Medicine \& International Health [serial online]. August 2006;11(8):1295-1302.

23. Ferster K, Eichner E. Exertional Sickling Deaths in Army Recruits With Sickle Cell Trait. Military Medicine [serial online]. January 2012;177(1):56-59.

24. College Sports Scholarships. Athletic Divisions of the NCAA. http://www.collegesportsscholarships.com/ncaa-divisions-differences.htm

25. O’Connor F, Bergeron M, Cantrell J, Connes P, Harmon K, Ivy E, Kark J, Klossner D, Lisman P, Meyers B, O’Brien K, Ohene-Frempong K, Thompson A, Whitehead J, Deuster P. ACSM and CHAMP summit on sickle cell trat: mitigating risks for warfighters and athletes. Med Sci Sports Exerc. 2012; 44(11): 2045-2056.

26. Bile A, Le Gallais D, Mercier B, Martinez P, Ahmaidi S, Prefaut C. Anaerobic exercise components during the force-velocity test in sickle cell trait. Int J Sports Med. 1996; 17(4): 254-258.

27. Hue O, Julan M, Blonc S. Alactic anaerobic performance in subjects with sickle cell trait and hemoglobin AA. Int j Sports Med. 2002; 23(3) 174-177.

28. Vincent L, Feasson L, Oyono-Enguelle S. Skeletal muscle structural and energetic characteristics in subjects with sickle cell trait, alpha-thalassemia, or dual hemoglobinopathy. J Appl Physical. 2010; 1109(3): 728-734.

29. Le Gallais D, Prefaut C, Dulat C, Macabies J, Lonsdorfer J. Sickle cell trait in ivory coast athletic champions, 1956-1989. Int J Sports Med. 1991; 12(5): 509-510.

30. Connes P, Racinais S, Sra F. Does the pattern of repeated sprint ability differ between sickle cell trait carriers and healthy subjects. Int J Sports Med. 2006; 27(12): 937-942.

31. Connes P, Hue O, Hardy-Dessources M, Boucher J, Pichot V, Barthelemy J. Hemorheology and heart rate variability: is there a relationship? Clin Hemorheol Microcirc. 2008; 38(4): 257-265.

32. Le Gallais D, Prefaut C, Mercier J, Bile A, Bogui P, Lonsdorfer J. Sickle cell trait as a limiting factor for high-level performance in a semi-marathon. Int J Sports Med. 1994; 15(7): 399-402. 
33. Martin L, Sara F, Antoine-Jonville S, Connes P, Etienne-Julan M, Hue O. Ventilatory and lactic thresholds in subjects with sickle cell trait. Int J Sports Med. 2007; 28(11): 916-920.

34. Robinson J, Stone W, Asendorf A. Exercise capacity of black sickle cell trait males. Med Sci Sports.1976; 8(4): 244-245.

35. Sara F, Connes P, Hue O, Montout-Hedreville M, Etienne-Julan M, Hardy-Dessources M. Faster lactate transport across red blood cell membrane in sickle cell trait carriers. $J$ Appl Physiol. 2006; 100(2): 437-442.

36. Weisman I, Zeballos R, Johnson B. Effect of moderate inspiratory hypoxia on exercise performance in sickle cell trait. Am J Med. 1988; 84(6): 1033-1040.

37. Weisman I, Zeballos R, Martin T, Johnson B. Effect of army basic training in sickle cell trait. Arch Intern Med. 1988; 148(5): 1140-1144.

38. Ballas S, Mohandas N. Sickle red cell microrheology and sickle blood rheology. Microcirculation. 2004; 11(2): 209-225.

39. Hebbel R, Yamada O, Moldow C, Jacob H, White J, Eaton J. Abnormal adherence of sickle erythrocytes to cultured vascular endothelium: possible mechanism for microvascular occlusion in sickle cell disease. J Clin Invest. 1980; 65: 154-160.

40. Okpala I. Leucocyte adhesion and the pathophysiology of sickle cell disease. Curr Opin Hematol. 2006; 13(1): 40-44.

41. Gladwin M, Schechter A, Ognibene F. Divergent nitric oxide bioavailability in men and women with sickle cell disease. Circulation. 2003; 107(2): 271-278.

42. Key N, Derebail V. Sickle cell trait: novel clinical significance. Hematology Am Soc Hematol Educ program. 2010; 1: 418-422.

43. Tripette J, Alexy T, Hardy-Dessources M. Red blood cell aggregation, aggregate strength and oxygen transport potential of blood are abnormal in both homozygous sickle cell anemia and sickle-hemoglobin C disease. Haematologica. 2009; 94(8): 1060-1065.

44. Tripette J, Loko G, Samb A. Effects of hydration and dehydration on blood rheology in sickle cell trait carriers during exercise. Am J Physiol Heart Circ Physiol. 2010; 299(3): H908-914. 
45. Tripette J, Connes P, Beltan E. Red blood cell deformability and aggregation, cell adhesion molecules, oxidative stress and nitric oxide markers after a short term, submaximal, exercise in sickle cell trait carriers. Clin Hemorheol Microcirc. 2010; 45(1): 39-52.

46. Aufradet E, Monchanin G, Oyonno-Engelle S. Habitual physical activity and endothelial activation in sickle cell trait carriers. Med Sci Sports Exerc. 2010; 42(11): 1987-1994.

47. Monchanin G, Serpero L, Connes P. Plasma levels $f$ adhesion molecules ICAM-1 and VCAM-1 in athletes with sickle cell trait with or without alpha-thalassemia during endurance exercise and recovery. Clin Hemorheol Microcirc. 2008; 40(2): 89-97.

48. Monchanin G, Serpero L, Connes P. Effects of a progressive and maximal exercise on plasma levels of adhesion molecules in athletes with sickle cell trait with or without alphathalassemia. J Appl Physiol. 2007; 102(1): 169-173.

49. Tripette J, Hardy Dessources M, Sara F. Does repeated and heavy exercise impair blood rheology in carriers of sickle cell trait? Clin J Sports Med. 2007; 17(6): 465-470.

50. Beltan E, Chalabi T, Tripette J, Chout R, Connes P. Coagulation responses after a submaximal exercise in sickle cell trait carriers. Thromb Res. 2011; 127(2): 167-169.

51. Connes P, Tripette J, Chalabi T. Effects of strenuous exercise on bood coagulation activity in sickle cell trait carriers. Clin J Hemorheol Microcirc. 2008; 38(1): 13-21.

52. Tripette J, Connes P, Hedreville M. Patterns of exercise-related inflammatory response in sickle cell trait carriers. Br J Sports Med. 2010; 44(4):232-237.

53. Westerman M, Green D, Gilman-Sachs A. Coagulation changes in individulas with sickle cell trait. Am J Hematol. 2002; 69(2): 89-94.

54. Messonnier L, Samb A, Tripette J. Moderate endurance exercise is not a risk for rhabdomyolysis or renal failure in sickle cell trait carriers. Clin Hemorheol Microcirc. 2012; 51(3): 193-202.

55. Harrelson G, Fincher A, Robinson J. Acute exetional rhabdomyolysis and its relationship to sickle cell trait. J Athl Train. 1995; 30(4): 309-312.

56. Burke J, Seda G, Allen D, Knee T. A case of severe exercise-induced rhabdomyolysis associated with a weight-loss dietary supplement. Mil Med. 2007; 172(6): 656-658. 
57. Eichner E. Overcaffeination: low potassium and other perils. Curr Sports Med Rep. 2011; 10(3): 122-123.

58. Eichner E. Sickle cell considerations in athletes. Clin Sports Med. 2011; 30(3): 537-549.

59. Martin T, Weisman I, Zeballos R, Stephenson S. Exercise and hypoxia increase in sickling in venous blood from an exercising limb in individuals with sickle cell trait. Am J Med. 1989; 87(1): 48-56.

60. Sheikha A. Splenic syndrome in patients at high altitude with unrecognized sickle cell trait: splenectomy is often unnecessary. Can J Surg. 2005; 48(5): 377-381.

61. Connes P. Hemorheology and exercise: effects of warm environments and potential consequences for sickle cell trait carriers. Scand J Med Sci Sports. 2010; 20(3): S48-52.

62. Hedreville M, Connes P, Romana M. Central retinal vein occlusion in a sickle cell trait carrier after a cycling race. Med Sci Sports Exerc. 2009; 41(1): 14-18.

63. Kark J, Posey D, Schumacher H, Ruehle C. Sickle cell trait as a risk factor for sudden death in physical training. N Engl J Med. 1987; 317(13): 781-787.

64. Bergeron M, Cannon J, Hall E, Kutlar A. Erythrocyte sickling during exercise and thermal stress. Clin J Sport Med. 2004; 14(6): 354-356.

65. Kark J, Labotka R, Gardner J, Ward F. Prevention of exercise-related death unexplained by preexisting disease (EDU) associated with sickle cell trait (SCT) without hemoglobin $(\mathrm{Hb})$ screening or Hb specific management. Blood. 2010; 116(21): 416-417.

66. Chirico E, Martin C, Faes C. Exercise training blunts oxidative stress in sickle cell trait carriers. J Appl Physiol. 2012; 112(9): 1445-1453.

67. Eichner E. Sickle cell trait. J Sport Rehabil. 2007; 16(3): 197-203.

68. Vichinsky E, Hurst D, Earles A, Kleman K, Lubin B. Newborn screening for sickle cell disease:effect on mortality. Pediatrics. 1988; 81(6): 749-755.

69. American Society of Hematology. Statement on screening for sickle cell trait and athletic participation. www.hematology.org/Advocacy/Policy-Statements/7704.aspx. 2012. 
70. Jordan L, Smith-Whitley K, Treadwell M, Telfair J, Grant A, Ohene-Frempong K. Screening U.S. college athletes for their sickle cell disease carrier status. Am J Prev Med. 2011; 41(6): S406-412. 